\title{
Organic and Inorganic Hazardous Waste Stabilization Utilizing Fossil Fuel Combustion Waste Materials
}

\section{Topical Report}

\author{
Daniel A. Netzel \\ Dorothy C. Lane \\ Melissa A. Brown \\ Kimberly A. Raska \\ Jeffery A. Clark \\ Joseph F. Rovani
}

September 1993

Work Performed Under Cooperative Agreement No.: DE-FC21-86MC1 1076

For

U.S. Department of Energy

Office of Fossil Energy

Morgantown Energy Technology Center

Morgantown, West Virginia

By

Western Research Institute

University of Wyoming Research Corporation

Laramie, Wyoming 


\section{DISCLAIMER}

This report was prepared as an account of work sponsored by an agency of the United States Government. Neither the United States Government nor any agency thereof, nor any of their employees, makes any warranty, express or implied, or assumes any legal liability or responsibility for the accuracy, completeness, or usefulness of any information, apparatus, product, or process disclosed, or represents that its use would not infringe privately owned rights. Reference herein to any specific commercial product, process, or service by trade name, trademark, manufacturer, or otherwise does not necessarily constitute or imply its endorsement, recommendation, or favoring by the United States Government or any agency thereof. The views and opinions of authors expressed herein do not necessarily state or reflect those of the United States Government or any agency thereof.

This report has been reproduced directly from the best available copy.

Available to DOE and DOE contractors from the Office of Scientific and Technical Information, 175 Oak Ridge Turnpike, Oak Ridge, TN 37831; prices available at (615) 576-8401.

Available to the public from the National Technical Information Service, U.S. Department of Commerce, 5285 Port Royal Road, Springfield, VA 22161; phone orders accepted at (703) 487-4650. 


\section{DISCLAIMER}

Portions of this document may be illegible in electronic image products. Images are produced from the best available original document. 


\section{Organic and Inorganic Hazardous Waste Stabilization Utilizing Fossil Fuel Combustion Waste Materials}

\section{Topical Report}

Daniel A. Netzel

Dorothy C. Lane

Melissa A. Brown

Kimberly A. Raska

Jeffery A. Clark

Joseph F. Rovani

Work Performed Under Cooperative Agreement No.: DE-FC21-86MC11076

For

U.S. Department of Energy

Office of Fossil Energy

Morgantown Energy Technology Center

P.O. Box 880

Morgantown, West Virginia 26507-0880

By

Western Research Institute

University of Wyoming Research Corporation

365 North $9^{\text {th }}$ Street

Laramie, Wyoming 82070

September 1993 
LIST OF TABLES $\ldots \ldots \ldots \ldots \ldots \ldots \ldots \ldots \ldots \ldots \ldots \ldots \ldots \ldots \ldots \ldots$ iv

LIST OF FIGURES $\ldots \ldots \ldots \ldots \ldots \ldots \ldots \ldots \ldots \ldots \ldots \ldots \ldots \ldots$

SUMMARY $\ldots \ldots \ldots \ldots \ldots \ldots \ldots \ldots \ldots \ldots \ldots \ldots \ldots \ldots \ldots \ldots \ldots \ldots$ vii

INTRODUCTION $\ldots \ldots \ldots \ldots \ldots \ldots \ldots \ldots \ldots \ldots \ldots \ldots \ldots \ldots$

EXPERIMENTAL $\ldots \ldots \ldots \ldots \ldots \ldots \ldots \ldots \ldots \ldots \ldots \ldots \ldots \ldots \ldots \ldots \ldots \ldots$

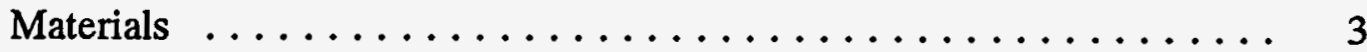

Innovative Clean Coal Technology Waste $\ldots \ldots \ldots \ldots \ldots \ldots$

Hazardous Wastes .................... 5

Synthetic Hazardous Waste $\ldots \ldots \ldots \ldots \ldots \ldots \ldots \ldots$

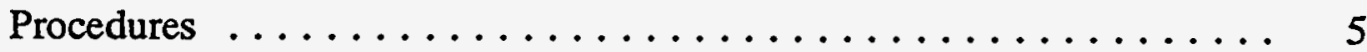

Chemical Characterization of the Hazardous Wastes $\ldots \ldots \ldots$. 5

Waste Mixtures Ratio ................... 5

Simulated Weathering Experiments $\ldots \ldots \ldots \ldots \ldots \ldots \ldots 6$

Aroclor 1260 Synthetic Waste $\ldots \ldots \ldots \ldots \ldots \ldots \ldots \ldots$. 7

Instrumentation $\ldots \ldots \ldots \ldots \ldots \ldots \ldots \ldots \ldots \ldots \ldots \ldots$

X-ray Diffraction . . . . . . . . .

Scanning Electron Microscopy/Energy Dispersive X-ray $\ldots \ldots .10$

Nuclear Magnetic Resonance ................. 10

RESULTS AND DISCUSSION $\ldots \ldots \ldots \ldots \ldots \ldots \ldots \ldots \ldots \ldots$

Hazardous Waste Characterization $\ldots \ldots \ldots \ldots \ldots \ldots \ldots \ldots \ldots, 11$

Mixed Metal Oxide-Hydroxide Waste ............ 11

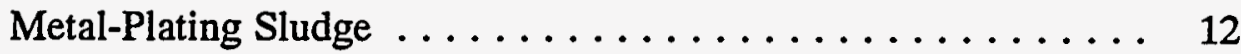

API Separator Sludge $\ldots \ldots \ldots \ldots \ldots \ldots \ldots \ldots \ldots \ldots \ldots$

Creosote-Contaminated Soil .................. 19 


\section{TABLE OF CONTENTS}

Page

Waste Mixing Ratio Study $\ldots \ldots \ldots \ldots \ldots \ldots \ldots \ldots \ldots$

Mixed Metal Oxide-Hydroxide . . . . . . . . . . . . 24

Metal-Plating Sludge $\ldots \ldots \ldots \ldots \ldots \ldots \ldots \ldots \ldots \ldots \ldots$

API Separator Sludge $\ldots \ldots \ldots \ldots \ldots \ldots \ldots \ldots \ldots \ldots$

Creosote-Contaminated Soil $\ldots \ldots \ldots \ldots \ldots \ldots \ldots$

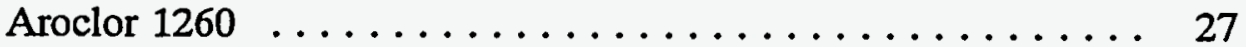

Simulated Weathering Study $\ldots \ldots \ldots \ldots \ldots \ldots \ldots \ldots \ldots, 28$

Nonequilibrium ....................... 28

Modified-Batch Equilibrium $\ldots \ldots \ldots \ldots \ldots \ldots \ldots$

X-ray Diffraction and Scanning Electron Microscopy/Energy X-ray

Analyses of Waste Mixtures from Nonequilibrium Simulated

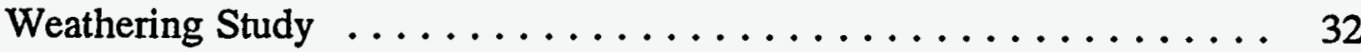

Solid-State ${ }^{13} \mathrm{C}$ NMR Investigation of Pentachlorophenol Adsorbed on TVA AFBC Waste $\ldots \ldots \ldots \ldots \ldots \ldots \ldots \ldots \ldots \ldots$

CONCLUSIONS $\ldots \ldots \ldots \ldots \ldots \ldots \ldots \ldots \ldots \ldots \ldots \ldots \ldots \ldots \ldots \ldots$

ACKNOWLEDGMENT ......................... 44

DISCLAIMER $\ldots \ldots \ldots \ldots \ldots \ldots \ldots \ldots \ldots \ldots \ldots \ldots \ldots \ldots \ldots$

REFERENCES $\ldots \ldots \ldots \ldots \ldots \ldots \ldots \ldots \ldots \ldots \ldots \ldots \ldots \ldots \ldots \ldots$ 
1. Innovative Clean Coal Technology Wastes $\ldots \ldots \ldots \ldots \ldots \ldots \ldots 4$

2. Aroclor 1260 Concentrations in Water Leachates of Spiked Samples ... 8

3. Aroclor 1260 Spiked Sand Sample Homogeneity $\ldots \ldots \ldots \ldots \ldots .9$

4. Total Metals Analysis of the Mixed Metal Oxide-Hydroxide Waste .... 11

5. Metal Analysis of the TCLP Extract of the Mixed Metal Oxide-

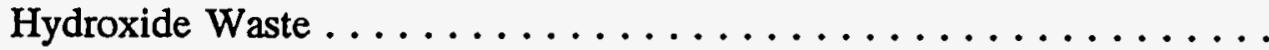

6. Total Metals Analysis of the Metal-Plating Sludge $\ldots \ldots \ldots \ldots \ldots$

7. Metal Analysis of the TCLP Extract of the Metal-Plating Sludge .... 13

8. Total Metals Analysis of the API Separator Sludge $\ldots \ldots \ldots \ldots \ldots$.

9. Metal Analysis of the TCLP Extract of the API Separator Sludge .... 14

10. Semivolatile Compounds Identified in the API Separator Sludge ..... 15

11. Semivolatile Compounds Identified in the TCLP Extract of the API

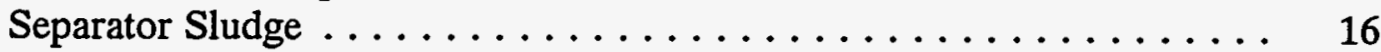

12. Semivolatile Compounds Tentatively Identified in the API Separator

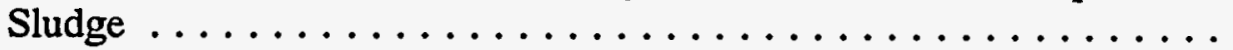

13. Semivolatile Compounds Tentatively Identified in the TCLP Extract of the API Separator Sludge $\ldots \ldots \ldots \ldots \ldots \ldots \ldots \ldots \ldots \ldots$

14. Volatile Analysis of the API Separator Sludge $\ldots \ldots \ldots \ldots \ldots \ldots$

15. Volatile Compounds Identified in the TCLP Extract of the API Separator Sludge $\ldots \ldots \ldots \ldots \ldots \ldots \ldots \ldots \ldots \ldots \ldots$

16. Total Metals Analysis of the Creosote-Contaminated Soil . . . . . . 19

17. Metal Analysis of the TCLP Extract of the Creosote-Contaminated

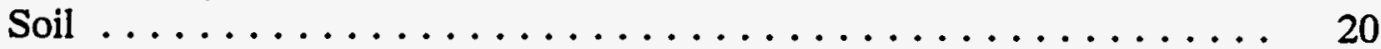

18. Semivolatile Compounds Identified in the Creosote-Contaminated

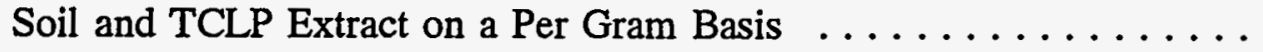


19. Semivolatile Compounds Identified in TCLP Extract of the CreosoteContaminated Soil . . . . . . . . . . . . . . . . . 21

20. Semivolatile Compounds Tentatively Identified in the CreosoteContaminated Soil . . . . . . . . . . . . . . . . . . 22

21. Semivolatile Compounds Tentatively Identified in the TCLP Extract of the Creosote-Contaminated Soil $\ldots \ldots \ldots \ldots \ldots \ldots \ldots \ldots \ldots 22$

22. Volatile Analysis of the Creosote-Contaminated Soil $\ldots \ldots \ldots \ldots 23$

23. Volatile Compounds Detected in the TCLP Extract of the CreosoteContaminated Soil $\ldots \ldots \ldots \ldots \ldots \ldots \ldots \ldots \ldots \ldots \ldots \ldots \ldots \ldots$

24. Variations of $\mathrm{pH}$ of Hazardous Wastes/ICCT Wastes Mixtures as a Function of Time Under Nonequilibrium Simulated Weathering Conditions .............................. 29

25. Variation of Chromium Concentration $(\mathrm{mg} / \mathrm{L})$ of Hazardous Wastes/ ICCT Wastes Mixtures as a Function of Time and Under Nonequilibrium Simulated Weathering Conditions ........... 30

26. Variations of $\mathrm{pH}$ of Hazardous Wastes/ICCT Wastes Mixtures as a Function of Time Under Modified-Batch Equilibrium Conditions ..... 31

27. Minerals Identified in the ICCT Wastes/Hazardous Wastes Mixtures . . . 32

28. Elemental and Mineralogical Analyses for the 90\% TVA AFBC Ash and $10 \%$ Metal Oxide-Hydroxide Waste Mixtures Used in Nonequilibrium Simulated Weathering Studies $\ldots \ldots \ldots \ldots \ldots \ldots 34$

29. Elemental and Mineralogical Analyses for the 90\% TVA AFBC Ash and 10\% API Separator Sludge Waste Mixture Used in Nonequilibrium Simulated Weathering Studies .................... 37

30. Elemental and Mineralogical Analyses for the $90 \%$ Colorado-Ute AFBC Ash and 10\% Metal Oxide-Hydroxide Waste Mixtures Used in Nonequilibrium Simulated Weathering Studies $\ldots \ldots \ldots \ldots \ldots . . .38$ 


\section{LIST OF FIGURES}

Eigure

Page

1. SEM Photomicrograph of $10 \%$ Metal Oxide-Hydroxide Hazardous

Waste Mixed with $90 \%$ ICCT TVA AFBC Ash . . . . . . . . . . .

2. SEM Photomicrograph of $10 \%$ Metal Oxide-Hydroxide Hazardous

Waste Mixed with $90 \%$ ICCT TVA AFBC Ash . . . . . . . . . .

3. SEM Photomicrograph of $10 \%$ Metal Oxide-Hydroxide Hazardous Waste Mixed with $90 \%$ ICCT TVA AFBC Ash . . . . . . . . 36

4. SEM Photomicrograph of $10 \%$ API Separator Sludge Hazardous

Waste Mixed with 90\% ICCT TVA AFBC Ash

5. SEM Photomicrograph of $10 \%$ Metal Oxide-Hydroxide Hazardous

Waste Mixed with $90 \%$ ICCT Colorado-Ute AFBC Ash .........

6. SEM Photomicrograph of $10 \%$ Metal Oxide-Hydroxide Hazardous Waste Mixed with $90 \%$ ICCT Colorado-Ute AFBC Ash . . . . . . .

7. ${ }^{13} \mathrm{C}$ Solid-State NMR Spectra of Pentachlorophenol (a) Technical Grade, SPE/MAS, Pd = 1 s, $43 \mathrm{~K}$ scans; (b) Adsorbed on TVA Coal Fly Ash, SPE/MAS, Pd = 1 s, $72 \mathrm{~K}$ scans; (c) After Leaching Fly Ash with Water, SPE/MAS, Pd = $1 \mathrm{~s}, 72 \mathrm{~K}$ scans; (d) After Leaching Fly Ash with Water, CP/MAS, ct $=5 \mathrm{~ms}, \mathrm{Pd}=1 \mathrm{~s}, 65 \mathrm{~K}$ scans. . . . . 


\section{SUMMARY}

A laboratory study was conducted at the Western Research Institute to evaluate the ability of innovative clean coal technology (ICCT) waste to stabilize organic and inorganic constituents of hazardous wastes. The four ICCT wastes used in this study were: (1) the Tennessee Valley Authority (TVA) atmospheric fluidized bed combustor (AFBC) waste, (2) the TVA spray dryer waste, (3) the Laramie River Station spray dryer waste, and (4) the Colorado-Ute AFBC waste.

Four types of hazardous waste stream materials were obtained and chemically characterized for use in evaluating the ability of the ICCT wastes to stabilize hazardous organic and inorganic wastes. The wastes included an API separator sludge, mixed metal oxide-hydroxide waste, metal-plating sludge, and creosote-contaminated soil. The API separator sludge and creosote-contaminated soil are U.S. Environmental Protection Agency (EPA)-listed hazardous wastes and contain organic contaminants. The mixed metal oxide-hydroxide waste and metal-plating sludge (also an EPA-listed waste) contain high concentrations of heavy metals. The mixed metal oxide-hydroxide waste fails the Toxicity Characteristic Leaching Procedure (TCLP) for cadmium, and the metal-plating sludge fails the TCLP for chromium.

To evaluate the ability of the ICCT wastes to stabilize the hazardous wastes, mixtures involving varying amounts of each of the ICCT wastes with each of the hazardous wastes were prepared, allowed to equilibrate, and then leached with deionized, distilled water. The leachates were analyzed for the hazardous constituent(s) of interest using the Toxicity Characteristic Leaching Procedure.

It was found that chromium was leached from both the Laramie River Station spray dryer and TVA spray dryer ICCT wastes. Thus, these materials cannot be used to stabilize hazardous materials containing chromium such as the metal-plating sludge. However, the four ICCT wastes can be used to stabilize the cadmium found in the metal oxide-hydroxide hazardous waste. 
In general, it was found that the mixtures of the ICCT wastes with the API separator sludge and creosote-contaminated soil are too complex for initial evaluation of the ability of the ICCT wastes to stabilize hazardous waste. However, the basicity of ICCT wastes may be used to stabilize the acidic components of the hazardous waste.

Simulated weathering experiments were performed using mixtures of TVA AFBC/metal oxide-hydroxide, Colorado-Ute AFBC/metal oxide-hydroxide, and TVA AFBC/API separator sludge. Evidence for stabilization of cadmium over time in the metal oxide-hydroxide mixtures and stabilization of organics in the mixture of the API separator sludge were observed.

$\mathrm{X}$-ray diffraction and scanning electron microscopy/energy dispersive X-ray analyses were performed on a number of ICCT wastes and hazardous wastes mixtures. Quartz and ettringite were the most dominant mineral phases in most of the mixtures. Other minerals identified include gypsum, portlandite, and calcite.

Solid-state ${ }^{13} \mathrm{C}$ nuclear magnetic resonance study was used to investigate the adsorption of pentachlorophenol on TVA AFBC waste. A downfield chemical shift of the phenolic carbon resonance in pentachlorophenol was observed when adsorbed on the TVA AFBC waste relative to the "free" solid-state position. The magnitude of the observed shift suggests a strong interaction of pentachlorophenol with the TVA AFBC waste.

This work was conducted under the U.S. Department of Energy, Jointly Sponsored Research program and is identified as Task 5.3, "Organic and Inorganic Hazardous Waste Stabilization", in Western Research Institute's Cooperative Agreement DE-FC21$86 \mathrm{MC} 11076$. 


\section{INTRODUCTION}

The implementation of innovative clean coal technologies (ICCT) to reduce $\mathrm{SO}_{\mathrm{X}} / \mathrm{NO}_{\mathrm{X}}$ emissions from coal-fired power plants has resulted in a new generation of solid waste materials that must be disposed. The use of ICCT wastes for hazardous inorganic and organic waste stabilization may be an effective alternative to or reduce the cost of conventional disposal. The high alkalinity of ICCT wastes may result in a significant reduction in the mobility of many heavy metals. Further, ICCT wastes may contain solids that can sorb organic compounds. In addition to being highly alkaline, some ICCT wastes may also possess environmentally deleterious properties, such as high leachate salinity, sodium, boron, and selenium levels. Combination of ICCT wastes with other types of waste materials may mitigate some of these problems that are associated with ICCT waste disposal. Thus, co-disposal of ICCT wastes with hazardous inorganic and organic waste materials may be an effective means of waste stabilization.

The chemical and mineralogical properties of ICCT waste materials, and consequently the chemical properties of ICCT waste leachates, are a function of the parameters (e.g., coal type) that influence conventional combustion waste (e.g., fly ash, bottom ash, flue gas, desulfurization sludge) characteristics (Rai et al. 1987; Ainsworth and Rai 1987) as well as the process used in $\mathrm{SO}_{X} / \mathrm{NO}_{X}$ emission reduction. In general, ICCT wastes may contain alkaline earth metal oxides (e.g., lime, periclase) and sulfates and sodium sulfate in addition to the oxides of aluminum, silicon, and iron, and calcium carbonate observed in conventional ash (Rai et al. 1987). Thus, ICCT wastes can be expected to be highly alkaline, saline, and possibly sodic (depending on $\mathrm{SO}_{\mathbf{X}} \mathrm{NO}_{\mathbf{X}}$ process). ICCT waste properties, as well as the properties of the conventional combustion wastes (co-disposed with the $\mathrm{SO}_{\mathrm{X}} / \mathrm{NO}_{\mathrm{X}}$ emission reduction wastes), may provide the necessary chemical and mineralogical environment to promote the chemical stabilization of other types of waste materials.

Hazardous wastes are materials that are considered hazardous because they fail the extraction procedure leachate test, the Toxicity Characteristic Leaching Procedure (TCLP), or are an U.S. Environmental Protection Agency (EPA)-listed waste. With respect to the extraction tests, wastes are deemed toxic if the values for certain inorganic elements and organic compounds exceed a statutory limit. Once a waste is listed as hazardous, parties that generate, transport, or dispose of such substances must comply with stringent regulations. Further, disposal sites must be monitored to ensure that no contaminants leach from the sites. If a particular hazardous waste can be made nonhazardous by combination with other waste materials, then land disposal is possible. 
When hazardous and ICCT waste materials are mixed, toxic compounds may be stabilized by a number of chemical processes. The dominant process for the stabilization of many inorganic constituents by alkaline materials is precipitation as carbonates, hydroxides, sulfates, silicates, or any number of complex solid phases. Additionally, many inorganics may be adsorbed by metal oxide phases present in the ICCT wastes. Arsenate and selenite retention by highly alkaline combusted solid wastes is related to the iron oxide content of the waste (Spackman et al. 1989a; 1989b). The behavior of hazardous organics in mixed-waste systems may be controlled by sorption reactions. Literature reviewed by Rai et al. (1987) suggests that fossil fuel combustion waste products have a high affinity for various classes of organic compounds.

The ability of ICCT waste materials to stabilize hazardous wastes has not been examined. Necessary components of such an evaluation must include extraction tests (e.g., TCLP) and tests to determine the ability of the waste mixtures to retain the hazardous components in weathering environments. Selective sequential extraction tests with weathered and unweathered alkaline solid wastes show that trace elements revert to more chemically resistant solid phases with increased weathering (Essington 1989). Thus, a toxicity evaluation conducted on waste mixtures shortly after mixing may not adequately assess potential hazards.

The objectives of this research are to evaluate the ability of solid waste products from clean coal technology combustion processes to stabilize hazardous organic and/or inorganic waste. This will involve (1) identifying, collecting, and characterizing hazardous waste materials and waste products from clean coal technology combustion processes, (2) evaluating the ability of the ICCT waste to stabilize the hazardous waste material using waste mixing ratio methodology, (3) studying the effects of simulated weathering on mixtures of ICCT wastes and hazardous wastes, (4) characterizing the mineralogical properties of ICCT waste and hazardous waste mixtures, and (5) investigating the use of solid-state ${ }^{13 \mathrm{C}}$ nuclear magnetic resonance (NMR) to study the bonding interactions between the ICCT waste and hazardous waste materials. 


\section{EXPERIMENTAL}

\section{Materials}

Innovative Clean Coal Technology Waste

Four ICCT waste materials from eastern and western coals were selected for this study. They are:

(1) The Tennessee Valley Authority (TVA) atmospheric fluidized bed combustor (AFBC) waste. This waste is from a 160 megawatt downstream system on unit 10 of the Shawnee Steam Plant in Paducah, Kentucky. The coal, which is $4 \%$ sulfur and $12 \%$ ash on a dry weight basis, is from the Pyramid Mine in Kentucky. At 160 megawatts, atmospheric fluidized bed combustion requires 122,000 pounds of coal per hour and 42,700 pounds of limestone per hour. The limestone that is used to control $\mathrm{SO}_{2}$ emission is $93 \% \mathrm{CaO}$ and $2 \% \mathrm{MgO}$. Seven hundred tons of waste, composed of $80 \%$ fly ash and $20 \%$ bottom ash, are produced per day. The bed drain waste contained $15 \% \mathrm{CaO}$ and the combusted char and fly ash contained 25 to $30 \% \mathrm{CaO}$.

(2) The TVA spray dryer waste. This waste is from a 10 megawatt pilot plant on unit 9 of the Shawnee Steam Plant in Paducah, Kentucky.

(3) The Colorado-Ute Electric Association AFBC waste. This waste is from a circulating fluidized bed combustion power plant (110 megawatt) in Nucla, Colorado that uses Salt Creek coal from the vicinity of Grand Junction, Colorado. The coal is $15.1 \%$ ash, $0.44 \%$ sulfur, $0.36 \% \mathrm{Ca}$, and $0.06 \% \mathrm{Mg}$. Limestone from a quarry just south of Telluride, Colorado is added (7\% of the coal that is burned). The limestone is $90 \% \mathrm{CaCO}_{3}$, $1.8 \% \mathrm{MgCO}_{3}$, and $8.2 \%$ silica and other impurities. The waste is expected to be alkaline with the potential for fixation of heavy metals and some organics.

(4) The Laramie River Station spray dryer waste. This waste is from unit 3 of the Laramie River Station which generates 570 kilowatts. A lime reagent system $(95 \% \mathrm{CaO})$ is used. The lime is from Townsend, Montana, and the coal is from the Powder River Basin, Wyoming.

Table 1 lists the elemental composition, as well as the site location of the ICCT wastes. 
Table 1. Innovative Clean Coal Technology Wastes

\begin{tabular}{|c|c|c|}
\hline & AFBC & Spray Dryer \\
\hline \multicolumn{3}{|l|}{ Eastern Coal } \\
\hline Facility & TVA & TVA \\
\hline Power Plant & Shawnee Steam Plant & Shawnee Steam Plant \\
\hline Coal & Pyramid Mine & Pyramid Mine \\
\hline$\% \mathrm{~S}$ & $4 \%$ & $4 \%$ \\
\hline$\%$ Ash & $12 \%$ & $12 \%$ \\
\hline Ash Mineral Carbon & $0.6 \%$ & $1.3 \%$ \\
\hline Ash Organic Carbon & $7.3 \%$ & $0.2 \%$ \\
\hline Location & Kentucky & Kentucky \\
\hline \multicolumn{3}{|l|}{ Limestone } \\
\hline$\% \mathrm{Ca}$ & $93 \%$ & $93 \%$ \\
\hline$\% \mathrm{Mg}$ & $2 \%$ & $2 \%$ \\
\hline$\%$ of Coal & $35 \%$ & \\
\hline \multicolumn{3}{|l|}{ Western Coal } \\
\hline Facility & Colorado-Ute & Basin Electric \\
\hline \multirow[t]{2}{*}{ Power Plant } & Colorado-Ute & Laramie River Station \\
\hline & Nucla, Colorado & Wheatland, Wyoming \\
\hline Coal & Salt Creek & Powder River \\
\hline$\% \mathrm{~S}$ & $0.44 \%$ & $<0.4 \%$ \\
\hline$\%$ Ash & $15.1 \%$ & $\sim 5 \% \pm 0.5 \%$ \\
\hline Ash Mineral Carbon & $0.2 \%$ & $0.5 \%$ \\
\hline Ash Organic Carbon & $4.6 \%$ & $0.1 \%$ \\
\hline Location & Grand Junction, Colorado & Wyoming \\
\hline \multicolumn{3}{|l|}{ Limestone } \\
\hline$\% \mathrm{Ca}$ & $90 \%$ & $95 \%$ \\
\hline$\% \mathrm{Mg}$ & $1.8 \%$ & None \\
\hline$\%$ of Coal & $7 \%$ & $0.1 \%$ \\
\hline
\end{tabular}




\section{Hazardous Wastes}

The specific source of the hazardous wastes used in this study cannot be disclosed because of contractual agreement with the supplier. The four waste materials consist of (1) an API separator sludge, (2) a creosote-contaminated soil, (3) a mixed metal oxidehydroxide waste, and (4) a metal-plating sludge. These four materials are EPA-listed hazardous wastes and failed the toxicity characteristic leaching procedure (TCLP) for inorganic analytes. Therefore, these materials were mixed with solid waste products from clean coal technology combustion processes to evaluate the ability of the ICCT wastes to stabilize the hazardous waste components.

\section{Synthetic Hazardous Waste}

A simulated Aroclor/transformer oil contaminated soil was used in the study. Aroclor 1260, a mixture of polychlorinated biphenyls (PCBs), is a resinous material that was selected for study as a result of its having been present in an Aroclor/transformer oil spill.

\section{Procedures}

\section{Chemical Characterization of the Hazardous Wastes}

Each of the wastes was blended for 6 hours in a batch mixer equipped with paddle-style blades to homogenize the material. After this process was completed, a random sample was withdrawn for TCLP characterization and total metals characterization by digestion and analysis using inductively coupled plasma (ICP) spectrometry and atomic absorption (AA) spectrometry. In addition, the API separator sludge and creosotecontaminated soil were analyzed for their semivolatile and volatile compounds. Volatiles were determined using EPA Method 624. Each of the wastes was also characterized by the TCLP for the Resource Conservation and Recovery Act (RCRA) metals, and the API separator sludge and creosote-contaminated soil TCLP extracts were analyzed for semivolatile and volatile compounds.

\section{Waste Mixtures Ratio}

Mixtures of the four hazardous wastes with the Colorado-Ute AFBC ash and TVA spray dryer waste were prepared using six different ratios for each solid-to-solid mixture. 
The mixtures that were prepared were $20 \%$ clean coal waste/80\% hazardous waste, $50 \%$ clean coal waste $/ 50 \%$ hazardous waste, $75 \%$ clean coal waste/25\%hazardous waste, $90 \%$ clean coal waste $/ 10 \%$ hazardous waste, $100 \%$ clean coal waste, and $100 \%$ hazardous waste. The mixtures were equilibrated for 7 days. At the end of the equilibration period, deionized, distilled water was added to each mixture to give a 1:1 solid-to-liquid ratio, and the slurries were allowed to equilibrate for an additional day. After the second equilibration period, the mixtures were filtered using a high-pressure filtration device equipped with nitrogen gas. The resulting filtrates were analyzed for the hazardous chemical constituent(s) of interest.

The ratio mixtures, prepared using the Aroclor spiked sand with the ICCT wastes, were shaken daily to increase contact between the sand and the ICCT waste. After 1 week, water was added to the mixtures. The slurries were allowed to equilibrate for 24 hours and then they were filtered.

\section{Simulated Weathering Experiments}

Nonequilibrium Weathering. The humidity cell experiments were conducted to characterize the behavior of organic and inorganic hazardous/ICCT waste mixtures under oxidizing, nonequilibrium conditions. The humidity cell experiments were performed in duplicate. The detailed procedure that was followed for the humidity cell experiments and a description of the apparatus are discussed by Caruccio (1968) and Sullivan et al. (1988). To summarize, a 1-kg sample of the waste mixture or ICCT waste was evenly spread out in the humidity cell (a Teflon-coated, $7-\mathrm{cm}$ deep by $33-\mathrm{cm}$ long by $25-\mathrm{cm}$ wide plastic container with snap-on Teflon-coated plastic lid) and the lid tightly sealed. Dry air was passed over the sample at a controlled rate for 3 days. From day 4 to day 7, humidified air was passed over the sample at a controlled rate. Exhaust air was passed through a cold-finger, to remove moisture, and an organic trap, to remove volatilized organics for frequent analysis where appropriate. On the seventh day, $1 \mathrm{~L}$ of deionizeddistilled water was added to the sample and allowed to equilibrate for 1 hour. After 1 hour the aqueous phase was removed, filtered for analysis, and the solids were returned to the humidity cell. This cycle was continued for no less than twelve sets. Immediately after the aqueous phase was removed, the leachate $\mathrm{pH}$ was measured. The leachate sample was split: one sample was acidified to $\mathrm{pH} 2$ with $\mathrm{HNO}_{3}$ and subjected to metals analysis by inductively coupled plasma (ICP) spectrometry and the other sample was subjected to organic analysis. 
Modified-Batch Equilibrium. The modified-batch equilibrations were conducted to characterize the behavior of organic and inorganic hazardous waste/ICCT waste mixtures and ICCT wastes under oxidizing equilibrium conditions. The modified-batch experiments were performed in triplicate. Hazardous/ICCT waste mixture samples of 100 to $200 \mathrm{~g}$ and a sufficient quantity of deionized-distilled water to produce a 1:2 solid-tosolution ratio were placed in $250 \mathrm{~mL}$ Teflon centrifuge bottles. The bottles were equipped with glass tubing through the cap to the bottom of the bottle and supplied with a constant flow of compressed humidified air. The bottles were placed in a water bath at a constant temperature of $25^{\circ} \mathrm{C}$. The samples were periodically shaken and weighed to determine water loss. Sample weight was maintained by the addition of deionizeddistilled water when necessary. The hazardous/ICCT waste mixtures and ICCT wastes were equilibrated with deionized-distilled water for 28 days. During the equilibration period, exhaust humidified air was passed through a cold-finger, to remove moisture, and an organic trap, to remove volatilized organics for analysis. At the end of the equilibration period, the solution phase was separated from the solid by centrifugation and filtration. The solution was split: one sample was acidified to $\mathrm{pH} 2$ with $\mathrm{HNO}_{3}$ and subjected to metals analysis by ICP and the other sample was subjected to organic analysis. The remaining solids were air-dried with a constant flow of dry air for volatile organic analysis, remoistened with deionized-distilled water to a solid-to-solution ratio of $1: 2$, and allowed to reequilibrate for a second 1-month period. This cycle was continued for 6 months.

At the completion of the equilibrium and nonequilibrium weathering studies, the solids from the hazardous/ICCT waste mixtures was subjected to TCLP extraction to assess the regulatory status of the weathered waste mixtures.

\section{Aroclor 1260 Synthetic Waste}

To determine an appropriate concentration of Aroclor 1260 to use in preparing the synthetic waste, dried sand samples were spiked with $2 \mathrm{ppm}, 20 \mathrm{ppm}, 200 \mathrm{ppm}$, and 1000 ppm Aroclor 1260. The sand samples were rotated end-over-end at 30 rotations per minute for 48 hours to homogenize the samples. After the 48-hour rotation, $250 \mathrm{~g}$ of sand from each spiked sample were mixed with $250 \mathrm{~g}$ of deionized, distilled water. The slurries were allowed to equilibrate for 24 hours and were then filtered using a highpressure filtration device with nitrogen gas. The resulting filtrates were then analyzed for Aroclor 1260. 
The concentrations of Aroclor 1260 determined to be present in the water leachates of the spiked sand samples are listed in Table 2. Based on these scattered results, a more thorough mixing was performed.

Table 2. Aroclor 1260 Concentrations in Water Leachates of Spiked Samples, $\mu \mathrm{g} / \mathrm{L}$

Leachate

Sand spiked with 2 ppm Aroclor 1260

Sand spiked with 20 ppm Aroclor 1260

Sand spiked with 200 ppm Aroclor 1260

Sand spiked with 1000 ppm Aroclor 1260

$\begin{array}{cc}\mathrm{A} & 3.8 \\ \mathrm{~B} & 2.6 \\ \mathrm{C} & 10.6\end{array}$

$\begin{array}{ll}\text { A } & 14.8 \\ \text { B } & 25.6 \\ \text { C } & 17.0\end{array}$

A $\quad 1800$

B 1200

A $\quad 630$

B 2900

The Aroclor 1260 spiked sand was rotated end-over-end at 30 rotations per minute for 14 days. After 14 days of mixing, $251-\mathrm{g}$ samples were withdrawn at random from the bulk material. The bulk sample was rotated end-over-end for an additional 7 days. After 7 days of mixing, one 1-g sample was withdrawn from the bulk material. The 26 samples were analyzed for Aroclor 1260. The data generated from the analysis of the first 25 samples were used to establish a 95\% confidence interval for the concentration of Aroclor 1260 in the spiked sand. The concentration of Aroclor 1260 in the 26th sample was compared to this $95 \%$ confidence interval. The criterion for homogeneity is that if the concentration of Aroclor 1260 in the sample withdrawn after additional mixing falls within the $95 \%$ confidence interval, the bulk material is homogenous. The concentration of Aroclor 1260 in the 26th sample did not fall within the $95 \%$ confidence interval, and as a result, the mixing procedure was repeated. After 2 additional weeks of mixing, seven samples were withdrawn from the bulk material and analyzed. One week later, an eighth sample of the Aroclor 1260 spiked sand was withdrawn to determine if 
the concentration of Aroclor 1260 in that sample would fall within the new confidence interval established using the data from the seven samples. The concentration of Aroclor 1260 in the eighth sample falls within both the $95 \%$ and $90 \%$ confidence intervals established using the data from the seven samples.

Results from the statistical evaluation of the data generated in testing the homogeneity of the Aroclor 1260 spiked sand are listed in Table 3. The data from the second set of analyses suggest that the Aroclor spiked sand has acceptable homogeneity for use in the ratio mixtures.

Table 3. Aroclor 1260 Spiked Sand Sample Homogeneity

25 samples analyzed for Aroclor 1260

$\overline{\mathrm{x}}=233 \mathrm{ng} / \mathrm{mL}$

$\mathrm{s}=39$

$95 \%$ confidence interval $=217-250 \mathrm{ng} / \mathrm{mL}$

After additional mixing, 1 sample withdrawn and analyzed, Aroclor $1260=409$ $\mathrm{ng} / \mathrm{mL}$

7 samples analyzed for Aroclor 1260 after 2 weeks of additional mixing

$\overline{\mathrm{x}}=266 \mathrm{ng} / \mathrm{mL}$

$\mathrm{s}=68$

$90 \%$ confidence interval $=213-319 \mathrm{ng} / \mathrm{mL}$

$95 \%$ confidence interval $=222-310 \mathrm{ng} / \mathrm{mL}$

\section{Instrumentation}

\section{$\underline{\text { X-ray Diffraction }}$}

X-ray diffraction analyses were done on mixtures made of $90 \%$ ICCT waste and $10 \%$ hazardous wastes. The samples were crushed using a mortar and pestle to $<1 \mathrm{~mm}$ and slurried with acetone. Approximately $2 \mathrm{~g}$ of each sample was mounted on glass cover slides in sample holders and allowed to air dry. Duplicate samples were prepared 
to test results. Bulk mineralogy of the ICCT wastes/hazardous waste mixtures was determined by X-ray diffraction analyses (XRD) using an automated, computer-driven Scintag PAD V diffractometer system. The diffractometer is equipped with an intrinsic germanium, solid-state detection system and computer-assisted, user-interactive diffraction management system. The system was operated at $45 \mathrm{kV}$ and $40 \mathrm{~mA}$ using Ni-filtered $\mathrm{CuK} \alpha$ radiation. Analyses were acquired from 2 to $70^{\circ} 2 \Theta$ at $2 \% \mathrm{~min}$. The diffractograms were compared to the Joint Committee on Powder Diffraction Standards (JCPDS) files for mineral phase identification.

\section{Scanning Electron Microscopy/Energy Dispersive X-ray}

The samples were mounted onto aluminum sample stubs and then coated with gold using an Edwards sputter coater S150B. X-ray diffraction and scanning electron microscopy/energy dispersive X-ray (SEM/EDX) analyses were performed using an Amray model 1820 computer-enhanced, digital-imaging scanning electron microscope (100-s count, $10.00 \mathrm{kV}$ ). The SEM is equipped with a Tracor Northern (Noran) model 5500 series II fully computer-operated energy dispersive X-ray analyzer (EDXA), which was used for elemental analysis.

\section{Nuclear Magnetic Resonance}

${ }^{13} \mathrm{C}$ solid-state NMR measurements were made using a Chemagnetics CMX $100 / 200$ solids NMR spectrometer. ${ }^{13} \mathrm{C}$ spectra were obtained at a ${ }^{13} \mathrm{C}$ frequency of 25 $\mathrm{MHz}$ using the techniques of single-pulse excitation with magic angle spinning (SPE/MAS) and cross-polarization with magic-angle spinning (CP/MAS) and high-power ${ }^{1} \mathrm{H}$ decoupling. A $12.5-\mathrm{mm}$ diameter zirconia bullet spinner was used. Spinning rates were between 3.5 and $3.6 \mathrm{kHz}$. The ${ }^{13} \mathrm{C}$ spectra were externally referenced to liquid tetramethylsilane (TMS) based on the solid-state spectrum of hexamethylbenzene (HMB) as the secondary reference and assigning $17.21 \mathrm{ppm}$ to the shift of the aliphatic carbons of HMB relative to liquid TMS (Hayashi and Hayamizu 1991). 


\section{RESULTS AND DISCUSSION}

\section{Hazardous Waste Characterization}

The four hazardous waste materials were chemically characterized for use in evaluating the ability of the ICCT wastes to stabilize hazardous organic and inorganic wastes. The hazardous wastes include: (1) mixed metal oxide-hydroxide, (2) a metalplating sludge, (3) an API separator sludge, and (4) a creosote-contaminated soil.

\section{Mixed Metal Oxide-Hydroxide Waste}

The concentrations on a per gram basis of the metals regulated under RCRA that are present in the mixed metal oxide-hydroxide waste are listed in Table 4. The concentrations in $\mathrm{mg} / \mathrm{L}$ of the RCRA-regulated metals that are leached by the TCLP are listed in Table 5. The mixed metal oxide-hydroxide waste is classified hazardous based on the concentration of cadmium ( $14.9 \mathrm{mg} / \mathrm{L}$ ) present in its TCLP extract. The regulatory limit for cadmium in the TCLP leachate is $1 \mathrm{mg} / \mathrm{L}$. As a result, the hazardous constituent of interest for examining the ability of ICCT waste to stabilize the mixed metal oxidehydroxide waste was chosen as cadmium.

Table 4. Total Metals Analysis of the Mixed Metal Oxide-Hydroxide Waste

\begin{tabular}{cclc}
\hline Metal & Concentration $^{\mathrm{a}}$ & Metal & Concentration $^{\mathrm{a}}$ \\
\hline $\mathrm{Ag}$ & 10.9 & $\mathrm{Fe}$ & $0.633 \%$ \\
$\mathrm{Al}$ & $<51$ & $\mathrm{Hg}^{\mathrm{c}}$ & 0.185 \\
$\mathrm{As}$ & $0.110 \%$ & $\mathrm{~K}$ & $<0.280 \%$ \\
$\mathrm{Ba}$ & 45 & $\mathrm{Mg}$ & $0.664 \%$ \\
$\mathrm{Ca}$ & $4.02 \%$ & $\mathrm{Ni}$ & $1.69 \%$ \\
$\mathrm{Cd}$ & $0.278 \%$ & $\mathrm{~Pb}$ & $0.313 \%$ \\
$\mathrm{Co}$ & $13.0 \%$ & $\mathrm{Se}$ & $<2$ \\
$\mathrm{Cr}$ & 191 & $\mathrm{~V}$ & 12 \\
$\mathrm{Cu}$ & $1.09 \%$ & $\mathrm{Zn}$ & $1.66 \%$ \\
\hline
\end{tabular}

a All units $\mathrm{mg} / \mathrm{kg}$ unless otherwise noted

b Determined by furnace atomic absorption spectrometry

c Determined by cold vapor atomic absorption spectrometry 
Table 5. Metal Analysis of the TCLP Extract of the Mixed Metal Oxide-Hydroxide Waste

\begin{tabular}{ccc}
\hline Metal & $\begin{array}{c}\text { Concentration } \\
\text { TCLP Extract }(\mathrm{mg} / \mathrm{L})\end{array}$ & $\begin{array}{c}\text { Concentration } \\
\text { TCLP Method Blank (mg/L) }\end{array}$ \\
\hline $\mathrm{Ag}$ & 0.08 & $<0.07$ \\
$\mathrm{As}^{\mathrm{a}}$ & 0.01 & $<0.005$ \\
$\mathrm{Ba}$ & 0.570 & $<0.10$ \\
$\mathrm{Cd}$ & 14.9 & $<0.10$ \\
$\mathrm{Cr}$ & $<0.08$ & $<0.08$ \\
$\mathrm{Hg}$ & $<0.002$ & $<0.002$ \\
$\mathrm{Ni}$ & 109 & $<0.20$ \\
$\mathrm{~Pb}$ & 0.240 & $<0.10$ \\
$\mathrm{Se}$ & $<0.05$ & $<0.05$ \\
$\mathrm{Tl}^{\mathrm{a}}$ & $<0.005$ & $<0.005$ \\
\hline
\end{tabular}

a Determined by furnace atomic absorption spectrometry

b Determined by cold vapor atomic absorption spectrometry

\section{Metal-Plating Sludge}

Table 6 lists the concentrations of the RCRA-regulated metals that are present in the metal-plating sludge. Table 7 lists the concentrations of the RCRA-regulated metals that are present in the TCLP extract of the metal-plating sludge. In addition to being an EPAlisted waste, the concentration of chromium $(18.0 \mathrm{mg} / \mathrm{L})$ in the TCLP extract of the metal-plating sludge exceeds the regulatory limit of $5.0 \mathrm{mg} / \mathrm{L}$. As a result, the hazardous constituent of interest for evaluating the ability of ICCT waste to stabilize the metalplating sludge was chosen as chromium.

\section{API Separator Sludge}

Data from the characterization of the API separator sludge for the concentrations of the RCRA-regulated metals are listed in Table 8. The amounts of the RCRA-regulated metals that are leached from the sludge by the TCLP are listed in Table 9. None of the concentrations listed in Table 9 exceed the regulatory limits. 
Table 6. Total Metals Analysis of the Metal-Plating Sludge

\begin{tabular}{cccc}
\hline Metal & Concentration $^{\mathrm{a}}$ & Metal & Concentration $^{\mathrm{a}}$ \\
\hline $\mathrm{Ag}$ & $<6.5$ & $\mathrm{Mg}$ & $<0.418 \%$ \\
$\mathrm{Al}$ & $0.118 \%$ & $\mathrm{Mn}$ & 108 \\
$\mathrm{As}$ & $<3.0$ & $\mathrm{Na}$ & $0.211 \%$ \\
$\mathrm{Ba}$ & 10.5 & $\mathrm{Ni}$ & $2.39 \%$ \\
$\mathrm{~B}$ & 623 & $\mathrm{~Pb}$ & 162 \\
$\mathrm{Ca}$ & $4.44 \%$ & $\mathrm{Sb}$ & $<50$ \\
$\mathrm{Cd}$ & $<5.0$ & $\mathrm{Se}^{\mathrm{b}}$ & $<3.0$ \\
$\mathrm{Co}$ & 22.1 & $\mathrm{Si}$ & 253 \\
$\mathrm{Cr}$ & $2.35 \%$ & $\mathrm{Sr}$ & 29.9 \\
$\mathrm{Cu}$ & $0.767 \%$ & $\mathrm{Th}$ & 119 \\
$\mathrm{Fe}$ & $0.247 \%$ & $\mathrm{Tl}$ & $<3.0$ \\
$\mathrm{Hg}$ & $<0.20$ & $\mathrm{Zn}$ & $0.105 \%$ \\
\hline
\end{tabular}

a All units $\mathrm{mg} / \mathrm{kg}$ unless otherwise noted

b Determined by furnace atomic absorption spectrometry

c Determined by cold vapor atomic absorption spectrometry

Table 7. Metal Analysis of the TCLP Extract of the Metal-Plating Sludge

\begin{tabular}{ccc}
\hline & $\begin{array}{c}\text { Concentration } \\
\text { TCLP Extract }(\mathrm{mg} / \mathrm{L})\end{array}$ & $\begin{array}{c}\text { Concentration } \\
\text { TCLP Method Blank (mg/L) }\end{array}$ \\
\hline $\mathrm{Ag}$ & $<0.10$ & $<0.10$ \\
$\mathrm{As}$ & $<0.005$ & $<0.005$ \\
$\mathrm{Ba}$ & 0.140 & $<0.10$ \\
$\mathrm{Cd}$ & $<0.10$ & $<0.10$ \\
$\mathrm{Cr}$ & 18 & $<0.10$ \\
$\mathrm{Hg}$ & $<0.002$ & $<0.002$ \\
$\mathrm{Ni}$ & 185 & $<0.10$ \\
$\mathrm{~Pb}$ & $<0.50$ & $<0.50$ \\
$\mathrm{Se}$ & $<0.10$ & $<0.10$ \\
$\mathrm{~T}^{\mathrm{a}}$ & $<0.01$ & $<0.01$ \\
\hline
\end{tabular}

a Determined by furnace atomic absorption spectrometry

b Determined by cold vapor atomic absorption spectrometry 
Table 8. Total Metals Analysis of the API Separator Sludge

\begin{tabular}{lrlr}
\hline Metal & Concentration $^{\mathrm{a}}$ & Metal & Concentration $^{\mathrm{a}}$ \\
\hline $\mathrm{Ag}$ & $<16$ & $\mathrm{Mg}$ & 11,720 \\
$\mathrm{Al}$ & 28,600 & $\mathrm{Mn}$ & 2,638 \\
$\mathrm{As}$ & 1,038 & $\mathrm{Na}$ & 3,515 \\
$\mathrm{Ba}$ & 122 & $\mathrm{Ni}$ & 476 \\
$\mathrm{Ca}$ & 75,000 & $\mathrm{~Pb}$ & 3,715 \\
$\mathrm{Cd}$ & 44 & $\mathrm{Se}$ & 931 \\
$\mathrm{Cr}$ & 1,600 & $\mathrm{Si}$ & 452 \\
$\mathrm{Cu}$ & 3,875 & $\mathrm{Sr}$ & 207 \\
$\mathrm{Fe}$ & 348,750 & $\mathrm{Zn}$ & 3,315 \\
\hline
\end{tabular}

a All units $\mathrm{mg} / \mathrm{kg}$ unless otherwise noted

b Determined by furnace atomic absorption spectrometry

Table 9. Metal Analysis of the TCLP Extract of the API Separator Sludge

\begin{tabular}{ccc}
\hline Metal & $\begin{array}{c}\text { Concentration TCLP } \\
\text { Extract }(\mathrm{mg} / \mathrm{L})\end{array}$ & $\begin{array}{c}\text { Concentration TCLP } \\
\text { Method Blank (mg/L) }\end{array}$ \\
\hline $\mathrm{Ag}$ & $<0.10$ & $<0.10$ \\
$\mathrm{As}$ & $<0.10$ & $<0.10$ \\
$\mathrm{Ba}$ & 0.55 & $<0.10$ \\
$\mathrm{Cd}$ & $<0.10$ & $<0.10$ \\
$\mathrm{Cr}$ & $<0.10$ & $<0.10$ \\
$\mathrm{Hg}$ & $<0.002$ & $<0.002$ \\
$\mathrm{Ni}$ & $<0.10$ & $<0.10$ \\
$\mathrm{~Pb}$ & $<0.50$ & $<0.50$ \\
$\mathrm{Se}$ & $<0.05$ & $<0.05$ \\
\hline
\end{tabular}

a Determined by furnace atomic absorption spectrometry

b Determined by cold vapor atomic absorption spectrometry 
During organic analyses, a search was made for 68 compounds. Only the semivolatile compounds listed in Table 10 were detected in the API separator sludge. The semivolatile compounds detected in the TCLP extract from the API separator sludge are listed in Table 11. Review of the data shows that there were some compounds extracted by the TCLP that were not detected in the waste. The reason for this is that the analysis of the API separator sludge is a high-concentration analysis that requires dilution, whereas analysis of the TCLP leachate is a low-concentration analysis. Because the extracts in the semivolatile analysis of the API separator sludge are diluted, some compounds may be diluted to a level below the method detection limit. The concentrations listed in Table 10 are in $\mathrm{mg} / \mathrm{kg}$ of waste, and the concentrations listed in Table 11 are in $\mu \mathrm{g} / \mathrm{L}$ of TCLP extract. For comparison, the amounts of 2methylnaphthalene and fluorene extracted from the API separator sludge by the TCLP on a per gram basis are $1.3 \mathrm{mg} / \mathrm{kg}$ of waste and an estimated $0.1 \mathrm{mg} / \mathrm{kg}$ of waste, respectively. None of the compounds listed in Table 11 are regulated under the toxicity characteristic of RCRA. In addition to the compounds listed in Table 10, Table 12 lists 10 semivolatile alkanes and their estimated concentration that have been tentatively identified in the API separator sludge. In addition to those listed in Table 11, compounds tentatively identified in the TCLP extract of the API separator sludge and their respective concentration are given in Table 13.

Table 10. Semivolatile Compounds Identified in the API Separator Sludge

Compound Concentration $(\mathrm{mg} / \mathrm{kg})$

2-Methylnaphthalene 14

Acenaphthene $4 \mathrm{~J}$

Fluorene $8 \mathrm{~J}$

Pentachlorophenol 18

Fluoranthene $1 \mathrm{~J}$

Pyrene $6 \mathrm{~J}$

$\mathrm{J}=$ Level detected is an estimate because it is below the method detection limit. 
Table 11. Semivolatile Compounds Identified in the TCLP Extract of the API Separator Sludge

\begin{tabular}{lcc}
\hline Compound & $\begin{array}{c}\text { Concentration } \\
\text { TCLP Extract }(\mu \mathrm{g} / \mathrm{L})\end{array}$ & $\begin{array}{c}\text { Concentration } \\
\text { TCLP Method Blank }(\mu \mathrm{g} / \mathrm{L})\end{array}$ \\
\hline 2,4-Dimethylphenol & 12 & $10 \mathrm{U}$ \\
Naphthalene & 57 & $10 \mathrm{U}$ \\
2-Methylnaphthalene & 66 & $10 \mathrm{U}$ \\
Fluorene & $5 \mathrm{~J}$ & $10 \mathrm{U}$ \\
Phenanthrene & $6 \mathrm{~J}$ & $10 \mathrm{U}$ \\
\hline
\end{tabular}

$\mathrm{U}=$ Extract was analyzed for the compound but it was not detected. Value given is the method detection limit.

$\mathrm{J}=$ Level detected is an estimate because it is below the method detection limit.

Table 12. Semivolatile Compounds Tentatively Identified in the API Separator Sludge

\begin{tabular}{lc}
\hline \multicolumn{1}{c}{ Compound Name } & $\begin{array}{c}\text { Estimated } \\
\text { Concentration }(\mathrm{mg} / \mathrm{kg})\end{array}$ \\
\hline Nonane, 4-methyl- or isomer & 20 \\
Decane or isomer & 26 \\
Tridecane or isomer & 21 \\
Tetradecane or isomer & 120 \\
Naphthalene, 1,2-dimethyl- or isomer & 89 \\
Pentadecane or isomer & 110 \\
Hexadecane or isomer & 76 \\
Heptadecane or isomer & 68 \\
Octadecane or isomer & 63 \\
Nonadecane or isomer & 60 \\
\hline
\end{tabular}


Table 13. Semivolatile Compounds Tentatively Identified in the TCLP Extract of the API Separator Sludge

\begin{tabular}{lc}
\hline \multicolumn{1}{c}{ Compound Name } & $\begin{array}{c}\text { Estimated } \\
\text { Concentration }(\mu \mathrm{g} / \mathrm{L})\end{array}$ \\
\hline Butanoic acid, 1-methylethyl ester or isomer & 77 \\
Benzene, 1-ethyl-2-methyl- or isomer & 69 \\
Benzene, 1,2,4-trimethyl- or isomer & 120 \\
1H-Indene, 2,3-dihydro- or isomer & 78 \\
Benzene, 1-ethyl-3,5-dimethyl- or isomer & 63 \\
1H-Indene, 2,3-dihydro-4-methyl- or isomer & 22 \\
Naphthalene, 1,2,3,4-tetrahydro-6-methyl- or isomer & 15 \\
Naphthalene, 1-methyl- or isomer & 37 \\
Naphthalene, 1,8-dimethyl- or isomer & 46 \\
\hline
\end{tabular}

Volatile organic compounds detected in the API separator sludge were toluene $(186 \mathrm{mg} / \mathrm{kg}$ ) and total xylenes $(2,700 \mathrm{mg} / \mathrm{kg}$ ) (see Table 14). Volatile compounds and their concentrations determined in TCLP extract of the API separator sludge (Table 15) were carbon disulfide $(9 \mu \mathrm{g} / \mathrm{L})$, trichloroethane $(6 \mu \mathrm{g} / \mathrm{L})$, total xylenes $(48 \mu \mathrm{g} / \mathrm{L})$, and benzene $(\sim 3 \mu \mathrm{g} / \mathrm{L}$, which is below the method detection limit). Once again, volatile compounds that were not detected in the API separator sludge were detected in its TCLP leachate due to the required dilution of the highly concentrated extracts in the analysis of the sludge. Of the $2,700 \mathrm{mg} / \mathrm{kg}$ of total xylenes detected in the API separator sludge, 960 $\mathrm{mg} / \mathrm{kg}$ was extracted by the TCLP. The TCLP regulatory level for carbon disulfide is 400 $\mu \mathrm{g} / \mathrm{L}$, and the regulatory level for benzene is $0.5 \mu \mathrm{g} / \mathrm{L}$.

Based on these data and because the API separator sludge is an EPA-listed organic waste, stabilization of the sludge by the ICCT waste in the ratio testing was evaluated based on the concentrations of organic semivolatile compounds. Volatile compounds were not evaluated because the ratio testing does not involve zero-headspace and, as a result, the volatile data would be inaccurate. 
Table 14. Volatile Analysis of the API Separator Sludge

Compound

Concentration (mg/kg)

Chloromethane

$50 \mathrm{U}$

Bromomethane

$50 \mathrm{U}$

Vinyl Chloride

$50 U$

Chloroethane

$50 \mathrm{U}$

Methylene Chloride

$35 \mathrm{~B}$

Acetone

$50 \mathrm{U}$

Carbon Disulfide

$25 \mathrm{U}$

1,1-Dichloroethene

$25 \mathrm{U}$

1,1-Dichloroethane

$25 \mathrm{U}$

1,2-Dichloroethene

$25 \mathrm{U}$

Chloroform

$25 \mathrm{U}$

1,2-Dichloroethane

$25 \mathrm{U}$

2-Butanone

$50 \mathrm{U}$

1,1,1-Trichloroethane

$25 \mathrm{U}$

Carbon Tetrachloride

$25 \mathrm{U}$

Vinyl Acetate

$50 \mathrm{U}$

Bromodichloromethane

$25 \mathrm{U}$

1,2-dichloropropane

$25 \mathrm{U}$

Trans-1,3-Dichloropropene

$25 \mathrm{U}$

Trichloroethene

$25 \mathrm{U}$

Dibromochloromethane

$25 \mathrm{U}$

1,1,2-Trichloroethane

$25 \mathrm{U}$

Benzene

$25 \mathrm{U}$

cis-1,3-Dichloropropene

$25 \mathrm{U}$

Bromoform

$25 \mathrm{U}$

4-Methyl-2-Pentanone

$50 \mathrm{U}$

2-Hexanone

$50 \mathrm{U}$

Tetrachloroethene

$25 \mathrm{U}$

1,1,2,2-Tetrachloroethane

$25 \mathrm{U}$

Toluene

190B

Chlorobenzene

$25 \mathrm{U}$

Ethylbenzene

$25 \mathrm{U}$

Styrene

$25 \mathrm{U}$

Total Xylenes

2700

$\mathrm{U}=$ Volatile extract was analyzed for the compound but it was not detected. Value given is the instrumental detection limit.

$\mathrm{B}=$ The analyte was found in the volatile instrumental blank as well as the sample. 22 $\mathrm{mg} / \mathrm{kg}$ of methylene chloride and $4 \mathrm{mg} / \mathrm{kg}$ of toluene were detected in the instrumental blank. 
Table 15. Volatile Compounds Identified in the TCLP Extract of the API Separator Sludge

\begin{tabular}{lccc}
\hline $\begin{array}{c}\text { Volatile } \\
\text { Compound }\end{array}$ & $\begin{array}{c}\text { Concentration } \\
\text { TCLP Extract } \\
(\mu \mathrm{g} / \mathrm{L})\end{array}$ & $\begin{array}{c}\text { Concentration } \\
\text { TCLP Method } \\
\text { Blank }(\mu \mathrm{g} / \mathrm{L})\end{array}$ & $\begin{array}{c}\text { Concentration } \\
\text { Instrument } \\
\text { Blank }(\mu \mathrm{g} / \mathrm{L})\end{array}$ \\
\hline Acetone & 200 & 230 & $10 \mathrm{U}$ \\
Carbon Disulfide & 9 & $5 \mathrm{U}$ & $5 \mathrm{U}$ \\
Trichloroethane & 6 & $5 \mathrm{U}$ & $5 \mathrm{U}$ \\
Benzene & $3 \mathrm{~J}$ & $5 \mathrm{U}$ & $5 \mathrm{U}$ \\
Total Xylenes & 48 & $5 \mathrm{U}$ & $5 \mathrm{U}$ \\
\hline
\end{tabular}

$\mathrm{U}=$ Extract/blank was analyzed for the compound but it was not detected. Value given is the instrumental detection limit.

$\mathrm{J}=$ Level detected is an estimate because it is below the instrumental detection limit.

\section{Creosote-Contaminated Soil}

Data from the characterization of the creosote-contaminated soil for the RCRAregulated metals are listed in Table 16. Table 17 lists the concentrations of the RCRAregulated metals present in the TCLP extract of the creosote-contaminated soil. None of the concentrations in Table 17 exceed the regulatory limits.

Table 16. Total Metals Analysis of the Creosote-Contaminated Soil

\begin{tabular}{cccc}
\hline Metal & Concentration $^{\mathrm{a}}$ & Metal & Concentration $^{\mathrm{a}}$ \\
\hline $\mathrm{Ag}$ & $<2.3$ & $\mathrm{Mg}$ & 15,300 \\
$\mathrm{Al}$ & 45,800 & $\mathrm{Mn}$ & 299 \\
$\mathrm{As}$ & $<23$ & $\mathrm{Mo}$ & $<4.6$ \\
$\mathrm{Ba}$ & 32.6 & $\mathrm{Ni}$ & 22 \\
$\mathrm{Ca}$ & 9,450 & $\mathrm{~Pb}$ & 26.5 \\
$\mathrm{Cd}$ & 8.3 & $\mathrm{Se}^{\mathrm{b}}$ & $<23$ \\
$\mathrm{Co}$ & 12.7 & $\mathrm{Si}$ & 60 \\
$\mathrm{Cr}$ & 39.2 & $\mathrm{~V}$ & 60.7 \\
$\mathrm{Cu}$ & 34.5 & $\mathrm{Zn}$ & 1,774 \\
$\mathrm{Fe}$ & 30,200 & & \\
\hline
\end{tabular}

a All units $\mathrm{mg} / \mathrm{kg}$ unless otherwise noted

b Determined by furnace atomic absorption spectrometry 
Table 17. Metal Analysis of the TCLP Extract of the Creosote-Contaminated Soil

\begin{tabular}{ccc}
\hline Metal & $\begin{array}{c}\text { Concentration } \\
\text { TCLP Extract }(\mathrm{mg} / \mathrm{L})\end{array}$ & $\begin{array}{c}\text { Concentration TCLP } \\
\text { Method Blank }(\mathrm{mg} / \mathrm{L})\end{array}$ \\
\hline $\mathrm{Ag}$ & $<0.10$ & $<0.10$ \\
$\mathrm{As}^{\mathrm{a}}$ & $<0.05$ & $<0.05$ \\
$\mathrm{Ba}$ & 1.27 & $<0.10$ \\
$\mathrm{Cd}$ & $<0.10$ & $<0.10$ \\
$\mathrm{Cr}$ & $<0.10$ & $<0.10$ \\
$\mathrm{Hg}$ & $<0.002$ & $<0.002$ \\
$\mathrm{Ni}$ & $<0.10$ & $<0.10$ \\
$\mathrm{~Pb}$ & $<0.50$ & $<0.50$ \\
$\mathrm{Se}^{\mathrm{a}}$ & $<0.05$ & $<0.05$ \\
\hline
\end{tabular}

a Determined by furnace atomic absorption spectrometry

b Determined by cold vapor atomic absorption spectrometry

The semivolatile compounds detected in the creosote-contaminated soil are listed in Table 18, along with the concentrations on a per gram basis of those compounds that were extracted from the waste by the TCLP. The semivolatile compounds extracted from the contaminated soil by the TCLP are listed in Table 19. None of the compounds listed in Table 19 are regulated under the toxicity characteristic of RCRA.

Compounds tentatively identified in the creosote-contaminated soil and in the corresponding TCLP extract are given in Tables 20 and 21, respectively. No volatile compounds were detected in the creosote-contaminated soil (Table 22) or its TCLP extract (Table 23). It should be noted that the volatile compounds listed in Table 23 of the TCLP extract of the creosote-contaminated soil are less than the blank concentrations.

Like the API separator sludge, the creosote-contaminated soil is an organic waste and is EPA listed. Stabilization of this waste was also evaluated based on the concentrations of organic semivolatile compounds. 
Table 18. Semivolatile Compounds Identified in the Creosote-Contaminated Soil and TCLP Extract on a Per Gram Basis

\begin{tabular}{lcc}
\hline \multicolumn{1}{c}{ Compound } & $\begin{array}{c}\text { Concentration in } \\
\text { the Waste }(\mathrm{mg} / \mathrm{kg})\end{array}$ & $\begin{array}{c}\text { Concentration in the } \\
\text { TCLP Extract }(\mathrm{mg} / \mathrm{kg})\end{array}$ \\
\hline Naphthalene & $12 \mathrm{~J}$ & 1.1 \\
2-Methylnaphthalene & $14 \mathrm{~J}$ & $--\mathrm{a}^{-}$ \\
Acenaphthylene & $25 \mathrm{~J}$ & 0.84 \\
Acenaphthene & 550 & -- \\
Dibenzofuran & $25 \mathrm{~J}$ & $0.08 \mathrm{~J}$ \\
Fluorene & 110 & 0.46 \\
Phenanthrene & 130 & $0.32 \mathrm{~J}$ \\
Anthracene & 500 & 1.0 \\
Fluoranthene & 810 & 1.5 \\
Pyrene & 710 & 0.66 \\
Benzo(a)anthracene & 300 & -- \\
Chrysene & 400 & $0.04 \mathrm{~J}$ \\
Benzo(b)fluoranthene & 120 & -- \\
Benzo(k)fluoranthene & $92 \mathrm{~J}$ & -- \\
Benzo(a)pyrene & 120 & -- \\
Indeno(1,2,3-cd)pyrene & $31 \mathrm{~J}$ & -- \\
Benzo(g,h,i)perylene & $20 \mathrm{~J}$ & -- \\
\hline
\end{tabular}

$J=$ Level detected is an estimate because it is below the method detection limit.

${ }^{a}$ Not detected in TCLP extract

Table 19. Semivolatile Compounds Identified in TCLP Extract of the CreosoteContaminated Soil

\begin{tabular}{lcc}
\hline Compound & $\begin{array}{c}\text { Concentration } \\
\text { TCLP Extract }(\mu \mathrm{g} / \mathrm{L})\end{array}$ & $\begin{array}{c}\text { Concentration TCLP } \\
\text { Method Blank }(\mu \mathrm{g} / \mathrm{L})\end{array}$ \\
\hline Benzoic Acid & $33 \mathrm{~J}$ & $50 \mathrm{U}$ \\
Naphthalene & 57 & $10 \mathrm{U}$ \\
Acenaphthylene & 42 & $10 \mathrm{U}$ \\
Dibenzofuran & $4 \mathrm{~J}$ & $10 \mathrm{U}$ \\
Fluorene & 23 & $10 \mathrm{U}$ \\
Phenanthrene & $16 \mathrm{~J}$ & $10 \mathrm{U}$ \\
Anthracene & 50 & $10 \mathrm{U}$ \\
Fluoranthene & 73 & $10 \mathrm{U}$ \\
Pyrene & 33 & $10 \mathrm{U}$ \\
Chrysene & $2 \mathrm{~J}$ & $10 \mathrm{U}$ \\
$\mathrm{U}=$ Extract was analyzed for the compound but it was not detected. Value given is the \\
method detection limit. & \\
$\mathrm{J}=$ Level detected is an estimate because it is below the method detection limit.
\end{tabular}


Table 20. Semivolatile Compounds Tentatively Identified in the CreosoteContaminated Soil

\begin{tabular}{lc}
\hline Compound Name & $\begin{array}{c}\text { Estimated Concentration } \\
(\mathrm{mg} / \mathrm{kg})\end{array}$ \\
\hline Possible $\mathrm{C}_{13} \mathrm{H}_{12}$ isomer & 110 \\
9H-Carbazole or isomer & 120 \\
$4 \mathrm{H}-$ Cyclopenta[def] phenanthrene or isomer & 200 \\
9,10-Anthracenedione or isomer & 94 \\
11H-Benzo[b]fluorene or isomer & 76 \\
Pyrene, 1-methyl- or isomer & 170 \\
Pyrene, 1-methyl- or isomer & 140 \\
Pyrene, 4-methyl- or isomer & 76 \\
Triphenylene or isomer & 51 \\
\hline
\end{tabular}

Table 21. Semivolatile Compounds Tentatively Identified in the TCLP Extract of the Creosote-Contaminated Soil

\begin{tabular}{lc}
\hline \multicolumn{1}{c}{ Compound Name } & $\begin{array}{c}\text { Estimated Concentration } \\
(\mu \mathrm{g} / \mathrm{L})\end{array}$ \\
\hline Butanoic acid, 1-methylethyl ester or isomer & 60 \\
3-methylbenzo[B]thiophene or isomer & 34 \\
Possible $\mathrm{C}_{13} \mathrm{H}_{16}$ isomer & 14 \\
Ethanone, 1-[1,1'-biphenyl]-4-yl- or isomer & 110 \\
$\mathrm{C}_{14} \mathrm{H}_{10}$ isomer & 50 \\
Phenanthrene, 4-methyl- or isomer & 36 \\
Possible $\mathrm{C}_{12} \mathrm{H}_{6} \mathrm{O}_{3}$ isomer & 82 \\
9,10-Anthracenedione or isomer & 72 \\
\hline
\end{tabular}


Table 22. Volatile Analysis of the Creosote-Contaminated Soil

\begin{tabular}{|c|c|}
\hline Compound & Concentration $(\mu \mathrm{g} / \mathrm{kg})$ \\
\hline Chloromethane & $25 U$ \\
\hline Bromomethane & $25 U$ \\
\hline Vinyl Chloride & $25 \mathrm{U}$ \\
\hline Chloroethane & $25 \mathrm{U}$ \\
\hline Methylene Chloride & $9 J$ \\
\hline Acetone & $25 \mathrm{U}$ \\
\hline Carbon Disulfide & $12.5 \mathrm{U}$ \\
\hline 1,1-Dichloroethene & $12.5 \mathrm{U}$ \\
\hline 1,1-Dichloroethane & $12.5 \mathrm{U}$ \\
\hline 1,2-Dichloroethene & $12.5 \mathrm{U}$ \\
\hline Chloroform & $12.5 \mathrm{U}$ \\
\hline 1,2-Dichloroethane & $12.5 \mathrm{U}$ \\
\hline 2-Butanone & $25 U$ \\
\hline 1,1,1-Trichloroethane & $12.5 U$ \\
\hline Carbon Tetrachloride & $12.5 \mathrm{U}$ \\
\hline Vinyl Acetate & $25 U$ \\
\hline Bromodichloromethane & $12.5 \mathrm{U}$ \\
\hline 1,2-Dichloropropane & $12.5 \mathrm{U}$ \\
\hline Trans-1,3-Dichloropropene & $12.5 U$ \\
\hline Trichloroethene & $12.5 \mathrm{U}$ \\
\hline Dibromochloromethane & $12.5 \mathrm{U}$ \\
\hline 1,1,2-Trichloroethane & $12.5 \mathrm{U}$ \\
\hline Benzene & $12.5 \mathrm{U}$ \\
\hline cis-1,3-Dichloropropene & $12.5 \mathrm{U}$ \\
\hline Bromoform & $12.5 U$ \\
\hline 4-Methyl-2-Pentanone & $25 U$ \\
\hline 2-Hexanone & $25 \mathrm{U}$ \\
\hline Tetrachloroethene & $12.5 \mathrm{U}$ \\
\hline 1,1,2,2-Tetrachloroethane & $12.5 \mathrm{U}$ \\
\hline Toluene & $4 \mathrm{~J}$ \\
\hline Chlorobenzene & $12.5 \mathrm{U}$ \\
\hline Ethylbenzene & $12.5 \mathrm{U}$ \\
\hline Styrene & $12.5 \mathrm{U}$ \\
\hline Total Xylenes & $12.5 \mathrm{U}$ \\
\hline
\end{tabular}

$U=$ Volatile extract was analyzed for the compound but it was not detected. Value given is the instrumental detection limit.

$\mathrm{J}=$ The analyte was found in the volatile instrumental blank as well as the sample. 2 $\mu \mathrm{g} / \mathrm{kg}$ of methylene chloride and $2 \mu \mathrm{g} / \mathrm{kg}$ of toluene were estimated in the instrumental blank. 
Table 23. Volatile Compounds Detected in the TCLP Extract of the CreosoteContaminated Soil

\begin{tabular}{lccc}
\hline $\begin{array}{c}\text { Volatile } \\
\text { Compound }\end{array}$ & $\begin{array}{c}\text { Concentration } \\
\text { TCLP Extract } \\
(\mu \mathrm{g} / \mathrm{L})\end{array}$ & $\begin{array}{c}\text { Concentration } \\
\text { TCLP Method } \\
\text { Blank }(\mu \mathrm{g} / \mathrm{L})\end{array}$ & $\begin{array}{c}\text { Concentration } \\
\text { Instrument } \\
\text { Blank }(\mu \mathrm{g} / \mathrm{L})\end{array}$ \\
\hline Methylene Chloride & $4 \mathrm{~J}$ & $3 \mathrm{~J}$ & $1 \mathrm{~J}$ \\
Acetone & 62 & 230 & $10 \mathrm{U}$ \\
2-Butanone & $7 \mathrm{~J}$ & $9 \mathrm{~J}$ & $10 \mathrm{U}$ \\
\hline
\end{tabular}

$\mathrm{U}=$ Extract/blank was analyzed for the compound but it was not detected. Value given is the instrumental detection limit.

$J=$ Level detected is an estimate because it is below the instrumental detection limit.

\section{Waste Mixing Ratio Study}

To evaluate the ability of the ICCT wastes to stabilize the various hazardous wastes, test mixtures were prepared using the following ratios of ICCT waste to hazardous waste: 20:80, 50:50, 75:25, 90:10, 100\% ICCT waste, and 100\% hazardous waste. The mixtures were equilibrated for 7 days, after which time slurries were prepared with water to yield a 1:1 solid to liquid ration. Filtrates from the slurries were analyzed to determine whether or not any indication of stabilization had occurred. Analysis for semivolatile organic compounds was performed for mixtures containing API separator sludge and creosotecontaminated soil. Mixtures containing metal-plating sludge were analyzed for chromium and those containing metal oxide-hydroxide waste were analyzed for cadmium. Selection of these analytes was based on studies previously described in this report.

\section{Mixed Metal Oxide-Hydroxide}

The filtrates from the mixtures of mixed metal oxide-hydroxide waste with the four innovative clean coal technology wastes were analyzed for cadmium. No cadmium was detected in the leachates from any of the $100 \%$ clean coal waste samples. The leachate from the $100 \%$ mixed metal oxide-hydroxide waste contained $0.15 \mu \mathrm{g}$ of cadmium per gram of waste. Mixing the mixed metal oxide-hydroxide waste with the clean coal wastes appears to reduce the leachability of cadmium from the waste. For all four clean coal wastes, no cadmium was detected in the leachates from the ratio mixtures. This is believed to be $\mathrm{pH}$ related. The $\mathrm{pH}$ of the filtrate from the $100 \%$ mixed metal oxide- 
hydroxide waste was 9 , and the $\mathrm{pH}$ values of the filtrates from the mixtures of the mixed metal oxide-hydroxide waste with the innovative clean coal technology wastes were approximately 12 . Cadmium hydroxide is not amphoteric and is less soluble at the higher $\mathrm{pH}$.

\section{Metal-Plating Sludge}

The filtrates from the mixtures of the metal-plating sludge with the four innovative clean coal technology wasted were analyzed for chromium. It was determined that approximately $2 \mathrm{ppm}$ and $0.2 \mathrm{ppm}$ chromium leach from a $100 \%$ sample of the Laramie River Station spray dryer waste and the TVA spray dryer waste, respectively, under the testing conditions used. As a result, these materials probably can not be used to stabilize the metal-plating sludge. In addition, mixing the metal-plating sludge with the TVA $\mathrm{AFBC}$ ash and $\mathrm{AFBC}$ ash from Colorado-Ute did not reduce the amount of chromium leached from the waste on a per gram basis. Higher concentrations of chromium were leached from the mixtures containing the clean coal wastes than from the $100 \%$ hazardous waste sample. This may be due to the higher $\mathrm{pH}$ of the waste/water slurry when the clean coal wastes are added. The $\mathrm{pH}$ of the filtrate from the $100 \%$ metal-plating sludge was 8 , and the $\mathrm{pH}$ values of the filtrates from the mixtures of the metal-plating sludge with the $A F B C$ ashes range from 11 to 12 . The amphoteric nature of chromium probably results in greater solubility of the hydroxide at high $\mathrm{pH}$.

\section{API Separator Sludge}

When the mixtures of API separator sludge and TVA AFBC ash were prepared, it was observed that the mixtures containing 20:80, 50:50, and 75:25 ratios of TVA-AFBC waste to API separator sludge released heat as the materials were combined. This is important because it indicates an exothermic reaction occurring between components of the two materials, and this reaction could play a role in stabilizing the hazardous components of the API separator sludge.

Semivolatile analyses were conducted on filtrates from ratio mixtures of the TVA AFBC ash, Laramie River Station spray dryer waste, and TVA spray dryer waste with the API separator sludge. The semivolatile analysis of the filtrate ( $\mathrm{pH} 3.9$ ) from the $100 \%$ API separator sludge sample identified the presence of several methyl and ethylsubstituted pyridine compounds. Similar compounds were also detected in the filtrates from the ratio mixtures involving the above three clean coal wastes, with the exception of the ratio mixtures involving $75 \%$ TVA AFBC ash/25\% API separator sludge and $90 \%$ 
TVA AFBC ash/10\% API separator sludge. No pyridine compounds were detected in these filtrates. The presence of ICCT wastes increased the alkalinity of the mixture slurries, yielding the neutral pyridine species that are easily extracted from aqueous solutions using typical organic analysis techniques. The filtrates from the TVA AFBC ash/API separator sludge mixtures all had $\mathrm{pH}$ values of approximately 12 . As a result, the absence of the pyridine compounds in the $75 \%$ and $90 \%$ mixtures does not appear to be $\mathrm{pH}$ related. The TVA AFBC ash contains significantly more organic carbon than the spray dryer wastes ( $7.3 \%$ versus $0.2 \%$ and $0.1 \%$ ) (see Table 1 ), and this higher organic carbon content may have some effect on the solubility of the pyridine compounds in the API separator sludge when it is mixed with larger amounts of the TVA AFBC ash.

Like the filtrates from mixtures of the API separator sludge with the TVA AFBC ash, Laramie River Station spray dryer waste, and TVA spray dryer waste, pyridine compounds were detected in the filtrates from mixtures of the API separator sludge with the Colorado-Ute AFBC ash. However, the pyridine concentrations in the filtrates do not seem to be affected by the amount of AFBC ash present in the ratio mixtures. Various other organic compounds were detected in the filtrates, but because of the complexity of the API separator sludge, no conclusions concerning stabilization of the sludge by this innovative clean coal technology waste can be made.

\section{Creosote-Contaminated Soil}

Little information could be obtained from the ratio mixtures involving the creosotecontaminated soil. Although measures were taken to homogenize the waste prior to preparing the ratio mixtures, it appears that the bulk sample of creosote-contaminated soil was not homogeneous. Data from the analysis of filtrates from two $100 \%$ creosotecontaminated soil/water slurries differed significantly. As a result, it is difficult to determine if concentration differences between the different mixtures are due to homogeneity problems or the presence of the clean coal wastes in the mixtures.

However, an overall observation that can be made (despite the fact that the bulk material was not homogeneous) is that compounds leached from the $100 \%$ creosotecontaminated soil samples were not detected in any of the filtrates from any of the $90 \%$ innovative clean coal technology waste/10\% creosote-contaminated soil mixtures.

The results obtained from mixtures involving the API separator sludge and creosotecontaminated soil clearly indicate that actual organic wastes are too complex for initial evaluation of the ability of combustion solid waste to stabilize organic wastes. Because 
homogenization of creosote contaminated soil was unsuccessful and the results of mixing with ICCT waste were inconclusive, an evaluation was conducted involving testing synthetic waste containing a single class of organic compounds such as acids, bases or neutrals or one or two major organic compounds representative of an organic waste type.

A simulated creosote waste containing six principal organic components of creosote was prepared. The simulated creosote consisted of pentachlorophenol, naphthalene, 1methylnaphthalene, phenanthrene, carbazole, and fluoranthene. Results indicate that pentachlorophenol is adsorbed by the ICCT wastes. The adsorption characteristics of ICCT wastes towards these compounds need to be studied individually. A tentative conclusion of these studies is that the basic characteristics of the ICCT wastes may be used to stabilize acidic components of hazardous wastes.

\section{Aroclor 1260}

As observed with homogenizing creosote-contaminated soils and ICCT wastes, attempts at homogenizing Aroclor solutions and ICCT wastes were unsuccessful. Some data, however, show that Aroclor 1260 was adsorbed by the ICCT wastes. No Aroclor 1260 was found in any of the samples extracted from Aroclor added to ICCT waste. This included samples from $150 \mu \mathrm{g}-400 \mu \mathrm{g}$ of Aroclor added directly to each waste and leached with water.

Aroclor 1260 in transformer oil was less dramatic. Transformer oil was added to each waste from 3.75 to $10 \%$ so that the Aroclor added was approximately the same amount as for those samples containing Aroclor alone. None of the samples adsorbed all of the Aroclor over the full range of concentrations.

The spray dryer waste from TVA was the most effective over the whole range of concentrations, while the spray dryer waste from the Laramie River Station was the least effective. In fact there is far more Aroclor in the water from the Laramie River Station spray dryer waste than is remotely possible due to the solubility of Aroclor in water alone. Therefore, oil droplets must have carried some Aroclor into the water which was subsequently extracted. After extensive experimentation with Aroclor systems, it was decided that adsorption characteristics of individual PCB's should be investigated prior to further Aroclor studies. Appropriate simplification of the complex Aroclor-ICCT waste systems should yield adsorption results that can be treated using Langmuir and Freundlich isotherms. 


\section{Simulated Weathering Study}

\section{Nonequilibrium}

Nonequilibrium simulated weathering experiments were performed using 10:90 ratios of mixtures of metal oxide-hydroxide/TVA AFBC ash, metal oxide-hydroxide waste/Colorado-Ute AFBC ash, and API separator sludge/TVA AFBC ash. Evidence for stabilization of organics in the API separator sludge over time were the main object of the weathering studies.

The first set of weathering experiments involved nonequilibrium humidity cell experiments in which the behavior of ICCT/hazardous waste mixtures in oxidizing media was characterized. Weekly sampling and analysis continued for 11 weeks. Measurements included $\mathrm{pH}$, metals, and semivolatile organics analyses. The $\mathrm{pH}$ results are summarized in Table 24.

The $\mathrm{pH}$ values for the sample mixtures decreased over the 11-week period. For all sample mixtures there was a slight increase in $\mathrm{pH}$ from weeks 1 through 3 and a general decrease for the remainder of the period. The $\mathrm{pH}$ of the sample mixtures with the TVA AFBC fly ash remained more alkaline throughout the 11-week weathering experiment. The $\mathrm{pH}$ values for the sample mixtures with the Colorado-Ute AFBC ash were initially similar to the other sample mixtures. The $\mathrm{pH}$ values for these mixtures decreased more than those for the mixtures with the TVA AFBC ash. The $\mathrm{pH}$ values became neutral and some values were acidic.

Barium, Calcium, Cadmium, Chromium, Potassium, Lithium, Molybdenum, Sodium, Strontium, Copper, Iron, Aluminum, Boron, Magnesium, Silicon, Cobalt, Iron, and Zinc were detected in the filtrates. The metals that were detected in the greatest concentrations initially decreased for the first 5 weeks, but later weeks showed an increase in calcium concentrations. The potassium concentration followed an opposite trend. The potassium concentration initially increased for the first five weeks and the concentration of potassium decreased in later weeks. The potassium concentration for the metal oxidehydroxide waste, Colorado-Ute AFBC ash mixture increased through week 4 and, for weeks 5 through 11, potassium was not detected in a concentration above the detection limit. The cadmium concentration was below the detection limit in all the filtrates. Chromium was consistently detected in all the filtrates. Chromium was detected in the greatest concentration in the filtrates from week 7 through 10 . Chromium results are summarized the Table 25 . 
Table 24. Variations of $\mathrm{pH}$ of Hazardous Wastes/ICCT Wastes Mixtures as a Function of Time Under Nonequilibrium Simulated Weathering Conditions

\begin{tabular}{|c|c|c|c|c|c|c|c|c|c|c|c|}
\hline \multirow[b]{2}{*}{ Sample Mixture ${ }^{a}$} & \multicolumn{11}{|c|}{ Week } \\
\hline & 1 & 2 & 3 & 4 & 5 & 6 & 7 & 8 & 9 & 10 & 11 \\
\hline $\mathrm{MO} / \mathrm{OH} / \mathrm{TVA}^{-1} \mathrm{~b}^{\mathrm{b}}$ & 12.37 & 12.44 & 13.10 & 12.64 & 12.26 & 12.70 & 11.51 & 11.47 & 11.11 & 11.22 & 11.06 \\
\hline MO/OH/TVA-2 & 12.01 & 12.50 & 13.10 & 12.47 & 12.33 & 12.83 & 11.61 & 11.27 & 11.27 & 11.50 & 11.23 \\
\hline $\mathrm{MO} / \mathrm{OH} / \mathrm{CO}-1^{\mathrm{c}}$ & 12.36 & 12.32 & 12.77 & 11.82 & 10.93 & 6.41 & 7.61 & 6.74 & 8.79 & 4.03 & 8.43 \\
\hline $\mathrm{MO} / \mathrm{OH} / \mathrm{CO}-2$ & 12.36 & 12.29 & 13.00 & 11.95 & 10.16 & 9.21 & 8.33 & 8.07 & 7.54 & 5.73 & 8.03 \\
\hline API/TVA- $1^{\mathrm{d}}$ & 12.11 & 12.20 & 13.11 & 12.46 & 12.50 & 12.30 & 11.45 & 11.12 & 11.22 & 11.25 & 10.65 \\
\hline API/TVA-2 & 12.42 & 12.54 & 13.21 & 12.14 & 12.30 & 12.60 & 11.41 & 10.83 & 10.99 & 11.33 & 11.34 \\
\hline Blank & 4.48 & 5.51 & 5.52 & 3.72 & 4.69 & 4.90 & 4.78 & 6.01 & 5.39 & 5.07 & 5.70 \\
\hline
\end{tabular}

${ }^{\text {a }}$ The samples consist of $10 \%$ hazardous waste/90\% ICCT waste mixtures in duplicate.

${ }^{b}$ Metal oxide-hydroxide - TVA AFBC ash (first sample)

${ }^{c}$ Metal oxide-hydroxide - Colorado-Ute AFBC ash (first sample)

d API sludge - TVA AFBC ash (first sample) 
Table 25. Variation of Chromium Concentration (mg/L) of Hazardous Wastes/ ICCT Wastes Mixtures as a Function of Time and Under Nonequilibrium Simulated Weathering Conditions

\begin{tabular}{|c|c|c|c|c|c|c|c|c|c|c|}
\hline \multirow[b]{2}{*}{ Sample Mixture ${ }^{\mathrm{a}}$} & \multicolumn{10}{|c|}{ Week } \\
\hline & 1 & 2 & 3 & 4 & 5 & 6 & 7 & 8 & 9 & 10 \\
\hline $\mathrm{MO} / \mathrm{OH} /$ TVA-1 $^{\mathrm{b}}$ & $<0.08$ & 0.16 & 0.20 & 0.18 & 0.16 & 0.10 & 0.28 & 0.30 & 0.30 & 0.25 \\
\hline MO/OH/TVA-2 & $<0.08$ & $<0.08$ & $<0.08$ & $<0.08$ & $<0.08$ & $<0.08$ & 0.19 & 0.14 & 0.24 & 0.17 \\
\hline $\mathrm{MO} / \mathrm{OH} / \mathrm{CO}-1^{\mathrm{c}}$ & 0.11 & $<0.08$ & $<0.08$ & 0.09 & $<0.08$ & $<0.08$ & 0.16 & 0.22 & 0.19 & 0.16 \\
\hline $\mathrm{MO} / \mathrm{OH} / \mathrm{CO}-2$ & 0.09 & $<0.08$ & $<0.08$ & $<0.08$ & $<0.08$ & $<0.08$ & 0.15 & 0.12 & 0.15 & 0.13 \\
\hline API/TVA- $1^{d}$ & $<0.08$ & $<0.08$ & $<0.08$ & $<0.08$ & $<0.08$ & $<0.08$ & 0.11 & 0.14 & 0.16 & 0.13 \\
\hline API/TVA-2 & $<0.08$ & $<0.08$ & 0.09 & 0.10 & $<0.08$ & $<0.08$ & 0.15 & 0.22 & 0.15 & 0.15 \\
\hline Blank & $<0.08$ & $<0.08$ & $<0.08$ & $<0.08$ & $<0.08$ & $<0.08$ & 0.17 & 0.12 & 0.12 & 0.10 \\
\hline
\end{tabular}

a The samples consist of $10 \%$ hazardous waste/90\% ICCT waste mixtures in duplicate.

${ }^{b}$ Metal oxide-hydroxide - TVA AFBC ash (first sample)

c Metal oxide-hydroxide - Colorado-Ute AFBC ash (first sample)

${ }^{d}$ API sludge - TVA AFBC ash (first sample) 
The organics observed from the metal oxide-hydroxide waste combined with the AFBC wastes from TVA and Colorado-Ute were tentatively identified as alkyl carboxylic acids or esters, with benzoic acid observed in some samples. Alkyl carboxylic acids, alkyl substituted benzoic acids or the ester analog were observed in mixtures of the API separator sludge with the TVA AFBC waste. It is not usually possible to distinguish organic carboxylic acids from the ester analog. Pyridines were observed in some the leachates from the API separator sludge. Pentachlorophenol, a relatively strong acid, was not observed.

\section{$\underline{\text { Modified-Batch Equilibrium }}$}

The modified-batch equilibrations were conducted in triplicate over a 6-month period to characterize the behavior of organic and inorganic hazardous waste/ICCT waste mixtures under oxidizing equilibrium conditions. The $\mathrm{pH}$ results are summarized in Table 26.

Table 26. Variations of $\mathrm{pH}$ of Hazardous/Wastes/ICCT Wastes Mixtures as a Function of Time Under Modified-Batch Equilibrium Conditions

\begin{tabular}{|c|c|c|c|c|c|c|}
\hline \multirow[b]{2}{*}{ Sample Mixture ${ }^{a}$} & \multicolumn{6}{|c|}{ Month } \\
\hline & 1 & 2 & 3 & 4 & 5 & 6 \\
\hline $\mathrm{MO} / \mathrm{OH} / \mathrm{TVA}^{-} \mathrm{1}^{\mathrm{b}}$ & 11.69 & 11.18 & 6.41 & 2.53 & 3.01 & 3.35 \\
\hline $\mathrm{MO} / \mathrm{OH} / \mathrm{TVA}-2$ & 11.90 & 11.70 & 11.14 & 11.63 & 3.68 & 2.35 \\
\hline $\mathrm{MO} / \mathrm{OH} / \mathrm{TVA}-3$ & 11.70 & 6.14 & 4.2 & 5.79 & 6.65 & 5.86 \\
\hline $\mathrm{MO} / \mathrm{OH} / \mathrm{CO}-1^{\mathrm{c}}$ & 4.75 & 5.96 & 4.39 & 7.63 & 6.84 & 8.10 \\
\hline $\mathrm{MO} / \mathrm{OH} / \mathrm{CO}-2$ & 4.65 & 5.67 & 6.87 & 4.33 & 8.71 & 3.55 \\
\hline $\mathrm{MO} / \mathrm{OH} / \mathrm{CO}-3$ & 4.43 & 11.53 & 11.44 & 2.20 & 2.20 & 2.90 \\
\hline API/TVA AFBC-1 ${ }^{d}$ & 11.84 & 11.37 & 12.34 & 12.21 & 11.93 & 11.56 \\
\hline API/TVA AFBC-2 & 11.76 & 11.11 & 11.57 & 2.23 & 2.28 & 2.51 \\
\hline API/TVA AFBC-3 & 11.65 & 11.56 & 11.09 & 11.54 & 2.50 & 2.48 \\
\hline Blank & 6.12 & 6.41 & 4.38 & 4.20 & 5.31 & 6.30 \\
\hline
\end{tabular}

a The samples consist of $10 \%$ hazardous waste/90\% ICCT waste mixtures in triplicate.

${ }^{b}$ Metal oxide-hydroxide - TVA AFBC ash (first sample)

${ }^{c}$ Metal oxide-hydroxide - Colorado-Ute AFBC ash (first sample)

${ }^{d}$ API sludge - TVA AFBC ash (first sample) 
As observed in the nonequilibrium weathering study for the metal oxide-hydroxide waste combined with the TVA AFBC waste, the organic compounds are tentatively identified as carboxylic acids or esters with from five to ten carbons. No organic priority pollutants were detected in any of the leachate samples. Concentrations of organics dropped somewhat over the 6 months. The concentrations of organics detected ranged from 10 to $1000 \mathrm{ppb}$ in leachates from the fourth sampling period. Inconsistencies were noted in the amounts of leachate obtained. For example, a greater amount of leachate was obtained from the first sample for the first month for the third triplicate mixture than the total amount of leachate obtained from the 6 months for the first mixture in the triplicate analyses. Similar compounds were observed for the mixtures of the metal oxide-hydroxide waste with Colorado-Ute AFBC waste. Leachates from mixtures of the API separator sludge and TVA AFBC waste showed no organic priority pollutants. Tentatively identified compounds included alkyl carboxylic and benzoic acids or esters.

\section{X-ray Diffraction and Scanning Electron Microscopy/Energy X-ray Analyses of Waste Mixtures from Nonequilibrium Simulated Weathering Study}

Two fly ashes, the TVA AFBC ash and Colorado-Ute AFBC ash and two waste types, a metal oxide-hydroxide waste and an API separator sludge waste, were analyzed by X-ray diffraction, scanning electron microscopy, and energy dispersive X-ray. Also three different mixtures were analyzed. These consisted of a mixture of TVA AFBC ash and metal oxide-hydroxide waste, TVA AFBC ash and API separator sludge, and Colorado-Ute AFBC ash mixed with metal oxide-hydroxide waste. The mineral phases that were identified in the ash/waste mixtures are listed in Table 27.

Table 27. Minerals Identified in the ICCT Wastes/Hazardous Wastes Mixtures

\begin{tabular}{ll}
\hline Mineral & Chemical Formula \\
\hline Calcite & $\mathrm{CaCO}_{3}$ \\
Clinoferrosilite & $(\mathrm{Fe}, \mathrm{Mg}) \mathrm{SiO}_{3}$ \\
Corundum & $\mathrm{Al}_{2} \mathrm{O}_{3}$ \\
Ettringite & $\mathrm{Ca}_{6} \mathrm{Al}_{2}\left(\mathrm{SO}_{4}\right)_{3}(\mathrm{OH})_{12} * 26 \mathrm{H}_{2} \mathrm{O}$ \\
Gypsum & $\mathrm{CaSo}_{4}{ }^{*} 2 \mathrm{H}_{2} \mathrm{O}$ \\
Hematite & $\mathrm{Fe}_{2} \mathrm{O}_{3}$ \\
Magnetite & $\mathrm{Fe}_{3} \mathrm{O}_{4}$ \\
Portlandite & $\mathrm{Ca}(\mathrm{OH})_{2}$ \\
Quartz & $\mathrm{SiO}_{2}$ \\
Potassium Sulfate & $\mathrm{K}_{2} \mathrm{~S}_{2} \mathrm{O}_{7}$ \\
Calcium Silicate Hydrate & $\mathrm{Ca}_{1.5} \mathrm{SiO}_{3.5} * \mathrm{H}_{2} \mathrm{O}$ \\
\hline
\end{tabular}


Quartz has been found to be mostly unaltered, detrital grains in most fly ashes (McCarthy, 1988; Hemmings and Berry 1988). Ettringite is commonly found in fly ash mixtures. Grutzeck et al. (1985) determined that fly ash spheres are a nucleation and growth site for ettringite. Carles-Gibergues and Aitcin (1986) wrote that ettringite was the reaction product of sulfates from Class F fly ashes. Also, ettringite has been found to slow down the rate of hydration (Grutzeck et al. 1985). McCarthy (1988) determined that gypsum is the product of the volatilization and sulfation of chlorides in the coal which generate hydrogen chloride and sulfates.

Table 28 lists the mineralogical and elemental analyses for the mixture of TVA $\mathrm{AFBC}$ ash and mixed metal oxide-hydroxide wastes. Ettringite was found to be the most abundant phase in most of the samples of this group. Calcium, silicon, and sulfur were the dominant elements identified in the SEM samples. Aluminum was found in most of the samples but not in the abundance of the other elements. Potassium and iron were identified in a couple of the samples, but no corresponding mineral phases were positively identified. Rod-like minerals, which may be ettringite, were identified in the samples (Figure 1). The rod-like minerals are very wide spread and cover most of the other material. This is shown in Figure 2. The curved shape of a fly ash sphere, surrounded and partially covered, can be seen in the middle of the photomicrograph. Blocky, irregular crystals were also identified in these samples (Figure 3). This phase was not seen in the other mixtures, and no elemental differences were noted.

The samples of TVA AFBC ash mixed with the API separator sludge waste are listed in Table 29. Mineralogically these samples were very similar to the TVA AFBC and metal oxide-hydroxide (TVA/OH) mixtures. Four mineral phases were tentatively identified in these samples that were not found in the TVA/OH mixtures. Potassium sulfate was identified as a minor constituent in one of the samples. Hematite, magnetite, and clinoferrosilite were all identified in another sample. Elemental analyses show that calcium, silicon, and sulfur are again the major components of the samples. Aluminum tends to be in higher concentrations than in the TVA/OH mixtures. Potassium is present in more than half of the samples. Iron and/or magnesium were identified in three of the samples. An SEM photomicrograph shows the rod-like phases very similar to the TVA/OH sample (Figure 4).

Quartz was the dominant phase identified in the Colorado-Ute AFBC ash and metal oxide-hydroxide (CU/OH) waste mixtures (Table 30). In general, these samples contained fewer mineral phase than the TVA samples. Quartz, calcite, and ettringite were the main phases identified for most of the samples. Additional phases identified were gypsum, portlandite, and corundum. Calcium, silicon, sulfur, aluminum, and a few occurrences of potassium were the elements identified in these samples. The rod-like minerals were also identified in the $\mathrm{CU} / \mathrm{OH}$ mixes, however, they appeared to be more congealed in some places than seen in the other mixture (Figure 5). Figure 6 shows fly ash sphere remnants, rod-like minerals, and a large, unidentified mineral phase. 
Table 28. Elemental and Mineralogical Analyses for the $90 \%$ TVA AFBC Ash and 10\% Metal Oxide-Hydroxide Waste Mixtures Used in Nonequilibrium Simulated Weathering Studies

\begin{tabular}{|c|c|c|c|c|c|}
\hline $\begin{array}{c}\text { Set } \\
\text { Number }\end{array}$ & $\begin{array}{l}\text { Sample } \\
\text { Number }\end{array}$ & Date & $\mathrm{pH}$ & Elemental Analyses & Mineralogical Analyses \\
\hline 2 & 1 & $10 / 2$ & 12.44 & $\mathrm{Ca}, \mathrm{Si}, \mathrm{S}, \mathrm{Al}$ (minor) & $\begin{array}{l}\text { Ettringite, Gypsum, Calcite, Quartz, } \\
\text { Portlandite, CaSi Hydrate }\end{array}$ \\
\hline 2 & 2 & $10 / 2$ & 12.50 & $\mathrm{Ca}, \mathrm{Si}, \mathrm{S}, \mathrm{Al}$ (minor) & $\begin{array}{l}\text { Ettringite, Portlandite, Quartz, } \\
\text { Calcite, Gypsum }\end{array}$ \\
\hline 4 & 1 & $10 / 21$ & 12.64 & $\mathrm{Ca}, \mathrm{Si}, \mathrm{S}, \mathrm{Al}, \mathrm{Fe}, \mathrm{K}$ & $\begin{array}{l}\text { Ettringite, Portlandite, Gypsum, } \\
\text { Quartz }\end{array}$ \\
\hline 4 & 2 & $10 / 21$ & 12.47 & $\mathrm{Ca}, \mathrm{Si}, \mathrm{S}$ & $\begin{array}{l}\text { Ettringite, Portlandite, Quartz, } \\
\text { Gypsum, Calcite, CaSi, Hydrate }\end{array}$ \\
\hline 6 & 1 & $11 / 4$ & 12.70 & $\mathrm{Ca}, \mathrm{Si}, \mathrm{S}, \mathrm{Al}, \mathrm{K}$ & $\begin{array}{l}\text { Ettringite, Gypsum, Portlandite, } \\
\text { Quartz }\end{array}$ \\
\hline 6 & 2 & $11 / 4$ & 12.83 & $\mathrm{Ca}, \mathrm{Si}, \mathrm{S}, \mathrm{Al}$ & Ettringite, Gypsum \\
\hline 8 & 1 & $11 / 18$ & 11.47 & $\mathrm{Ca}, \mathrm{Si}, \mathrm{S}, \mathrm{Al}$ & Ettringite, Quartz \\
\hline 8 & 2 & $11 / 18$ & 11.27 & $\mathrm{Ca}, \mathrm{Si}, \mathrm{S}, \mathrm{Al}, \mathrm{K}$ & $\begin{array}{l}\text { Ettringite, Calcite, Gypsum, } \\
\text { Portlandite, Quartz }\end{array}$ \\
\hline 10 & 1 & $12 / 2$ & 11.22 & $\mathrm{Ca}, \mathrm{Si}, \mathrm{S}, \mathrm{Al}$ & $\begin{array}{l}\text { Ettringite, Gypsum, Quartz, Portlandite } \\
\text { Calcite }\end{array}$ \\
\hline 10 & 2 & $12 / 2$ & 11.50 & $\mathrm{Ca}, \mathrm{Si}, \mathrm{S}, \mathrm{Al}$ & Ettringite, Quartz \\
\hline 12 & 1 & $12 / 18$ & 11.30 & $\mathrm{Ca}, \mathrm{Si}, \mathrm{S}, \mathrm{Al}$ & Calcite, Ettringite, Quartz, Portlandite \\
\hline 12 & 2 & $12 / 18$ & 11.27 & $\mathrm{Ca}, \mathrm{Si}, \mathrm{S}, \mathrm{Al}$ & Ettringite, Quartz \\
\hline
\end{tabular}




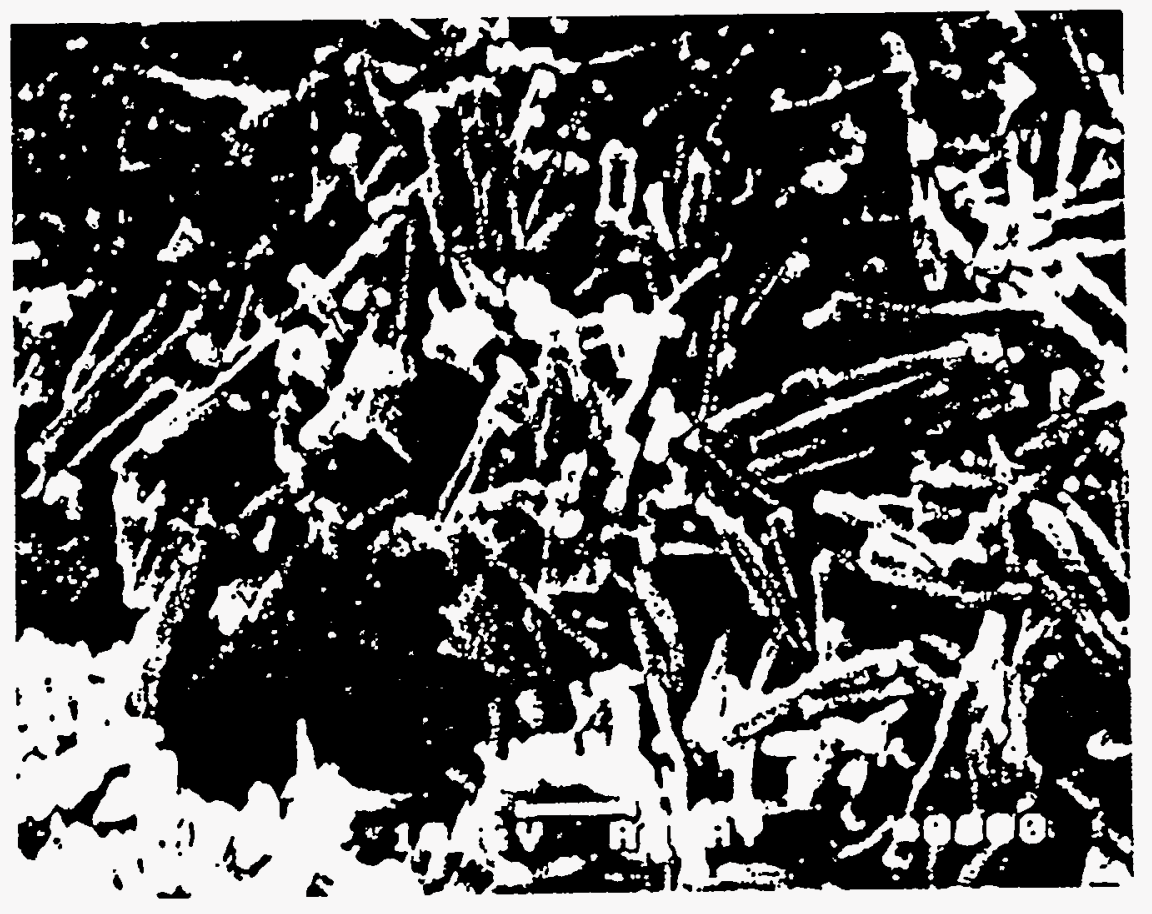

Figure 1. SEM Photomicrograph of $10 \%$ Metal Oxide-Hydroxide Hazardous Waste Mixed with 90\% ICCT TVA AFBC Ash

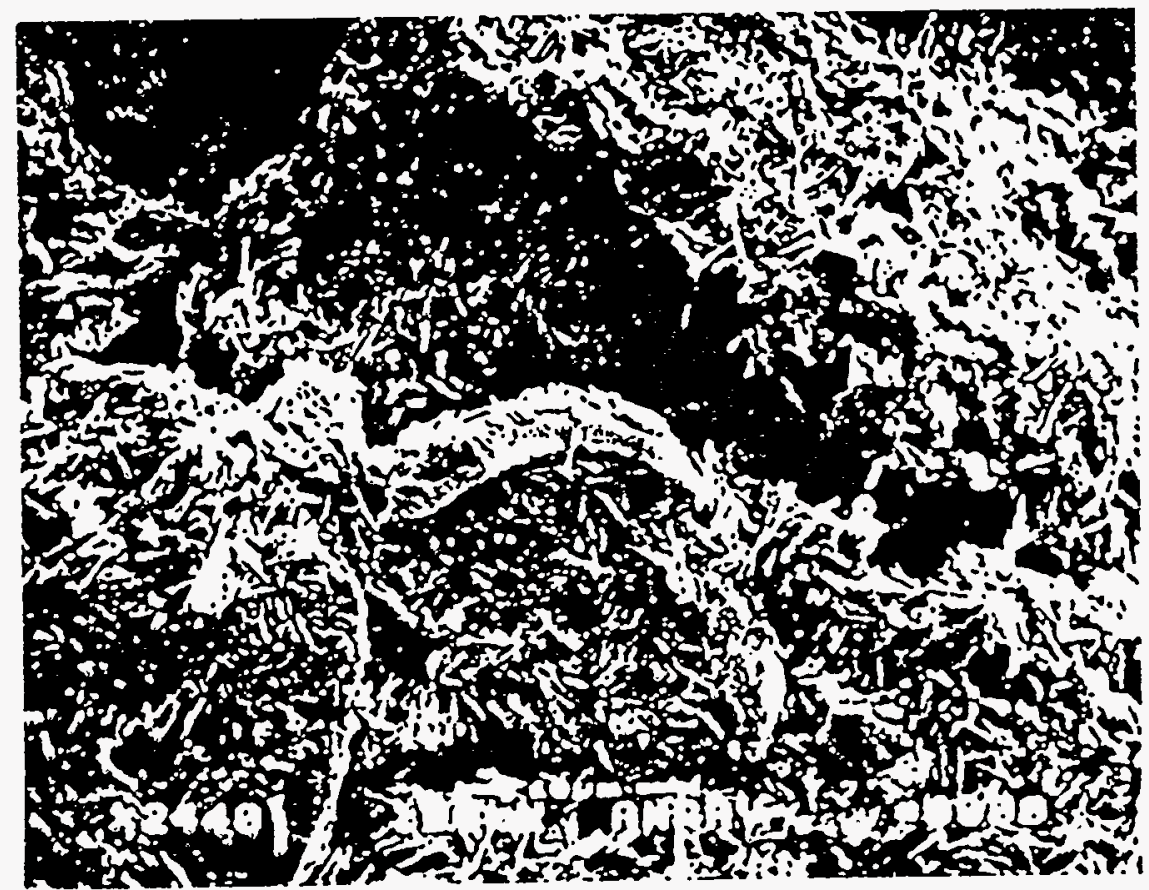

Figure 2. SEM Photomicrograph of $10 \%$ Metal Oxide-Hydroxide Hazardous Waste Mixed with 90\% ICCT TVA AFBC Ash 


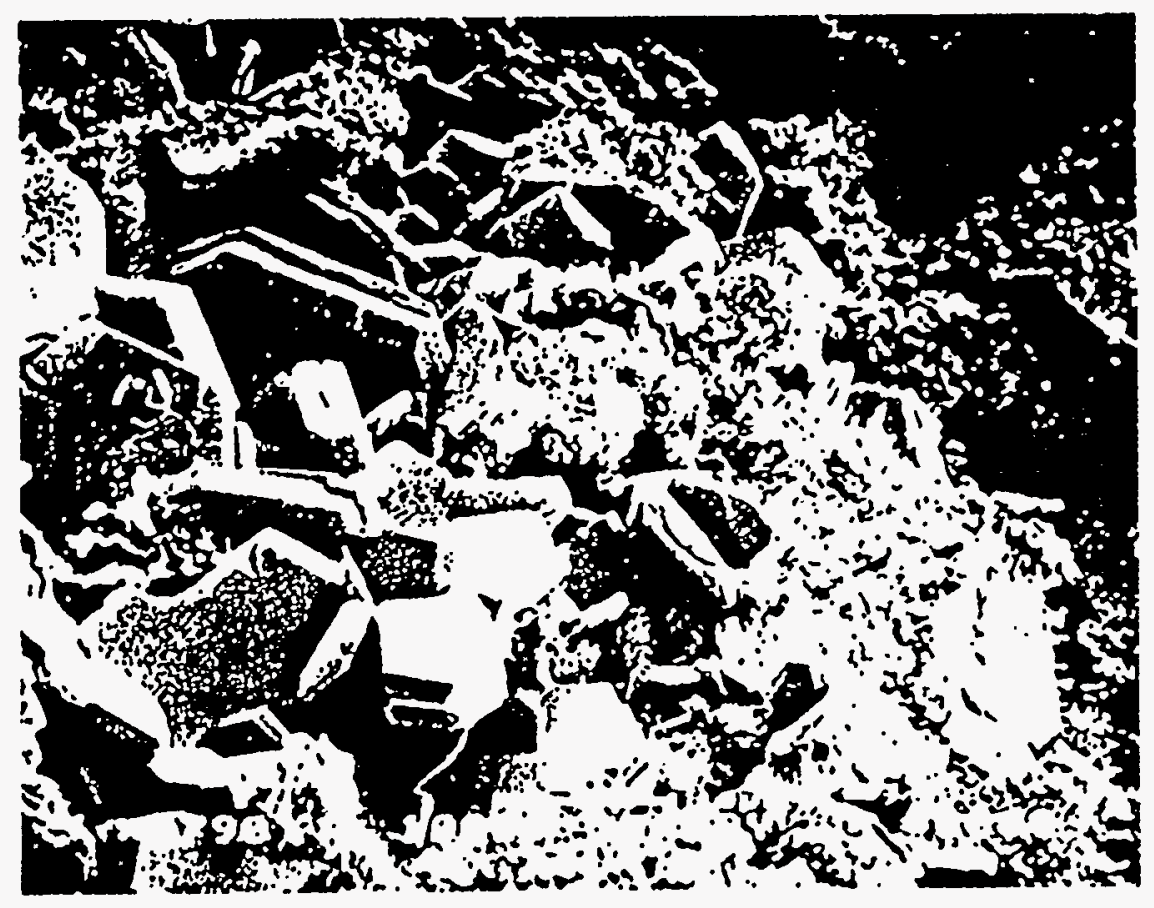

Figure 3. SEM Photomicrograph of $10 \%$ Metal Oxide-Hydroxide Hazardous Waste Mixed with 90\% ICCT TVA AFBC Ash

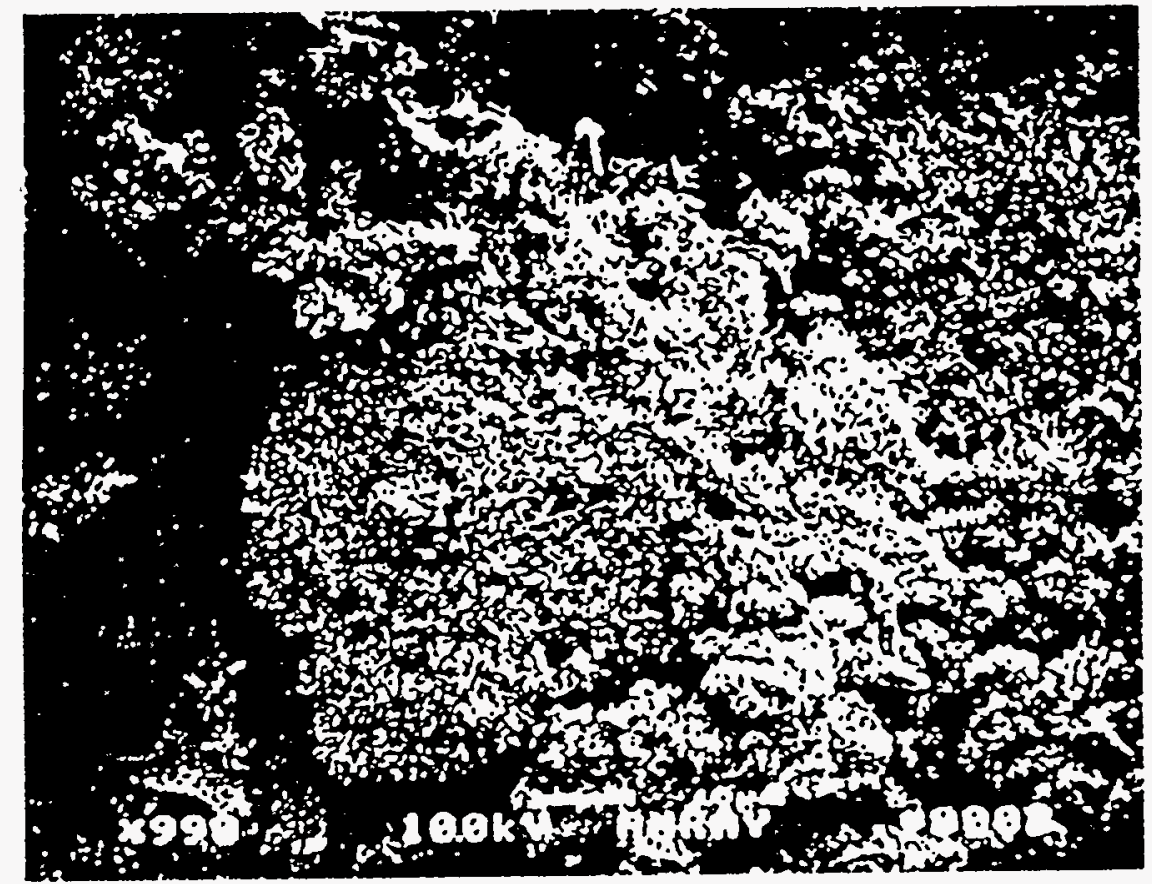

Figure 4. SEM Photomicrograph of $10 \%$ API Separator Sludge Hazardous Waste Mixed with $90 \%$ ICCT TVA AFBC Ash 
Table 29. Elemental and Mineralogical Analyses for the $90 \%$ TVA AFBC Ash and 10\% API Separator Sludge Waste Mixture Used in Nonequilibrium Simulated Weathering Studies

\begin{tabular}{|c|c|c|c|c|c|}
\hline $\begin{array}{c}\text { Set } \\
\text { Number }\end{array}$ & $\begin{array}{l}\text { Sample } \\
\text { Number }\end{array}$ & Date & $\mathrm{pH}$ & Elemental Analyses & Mineralogical Analyses \\
\hline 2 & 1 & $10 / 7$ & 12.20 & $\mathrm{Ca}, \mathrm{Si}, \mathrm{S}, \mathrm{Al}$ & $\begin{array}{l}\text { Ettringite, Calcite, Quartz, Gypsum, } \\
\text { Portlandite (minor), CaSi Hydrate } \\
\text { (minor) }\end{array}$ \\
\hline 2 & 2 & $10 / 7$ & 12.54 & $\mathrm{Ca}, \mathrm{Si}, \mathrm{S}, \mathrm{Al}, \mathrm{Fe}, \mathrm{K}$ & Ettringite, Gypsum, Quartz, Portlandite \\
\hline 4 & 1 & $10 / 21$ & 12.46 & $\mathrm{Ca}, \mathrm{Si}, \mathrm{S}, \mathrm{Al}, \mathrm{K}$ & Ettringite, Portlandite, Gypsum, Quartz \\
\hline 4 & 2 & $10 / 21$ & 12.14 & $\mathrm{Ca}, \mathrm{Si}, \mathrm{S}, \mathrm{Al}, \mathrm{K}$ & $\begin{array}{l}\text { Ettringite, Portlandite, Gypsum, Quartz, } \\
\mathrm{K}_{2} \mathrm{~S}_{2} \mathrm{O}_{7} \text { (minor) }\end{array}$ \\
\hline 6 & 1 & $11 / 4$ & 12.80 & $\mathrm{Ca}, \mathrm{Si}, \mathrm{S}, \mathrm{Al}, \mathrm{K}$ & Ettringite, Gypsum, Calcite, Portlandite \\
\hline 6 & 2 & $11 / 4$ & 12.60 & $\mathrm{Ca}, \mathrm{Si}, \mathrm{S}, \mathrm{Al}, \mathrm{Mg}, \mathrm{Fe}$ & Ettringite, Portlandite, Gypsum \\
\hline 8 & 1 & $11 / 18$ & 11.12 & $\mathrm{Ca}, \mathrm{Si}, \mathrm{S}, \mathrm{Al}$ & $\begin{array}{l}\text { Calcite, Ettringite, Quartz, Portlandite, } \\
\text { Gypsum }\end{array}$ \\
\hline 8 & 2 & $11 / 18$ & 10.83 & $\mathrm{Ca}, \mathrm{Si}, \mathrm{S}, \mathrm{Al}$ & $\begin{array}{l}\text { Ettringite, Portlandite, Gypsum, Quartz, } \\
\text { Calcite }\end{array}$ \\
\hline 10 & 1 & $12 / 2$ & 11.25 & $\mathrm{Ca}, \mathrm{Si}, \mathrm{S}, \mathrm{Al}$ & $\begin{array}{l}\text { Calcite, Ettringite, Quartz, Portlandite, } \\
\text { Gypsum }\end{array}$ \\
\hline 10 & 2 & $12 / 2$ & 11.33 & $\mathrm{Ca}, \mathrm{Si}, \mathrm{S}, \mathrm{Al}, \mathrm{Fe}, \mathrm{K}, \mathrm{Mg}$ & $\begin{array}{l}\text { Quartz, Calcite, Ettringite, Portlandite, } \\
\text { Hematite, Magnetite, Clinoferrosilite }\end{array}$ \\
\hline 12 & 1 & $12 / 18$ & 10.92 & $\mathrm{Ca}, \mathrm{Si}, \mathrm{S}, \mathrm{Al}, \mathrm{K}$ & Ettringite, Quartz, Calcite \\
\hline 12 & 2 & $12 / 18$ & 11.31 & $\mathrm{Ca}, \mathrm{Si}, \mathrm{S}, \mathrm{Al}, \mathrm{K}$ & Calcite, Ettringite, Quartz \\
\hline
\end{tabular}


Table 30. Elemental and Mineralogical Analyses for the 90\% Colorado-Ute AFBC Ash and 10\% Metal OxideHydroxide Waste Mixtures Used in Nonequilibrium Simulated Weathering Studies

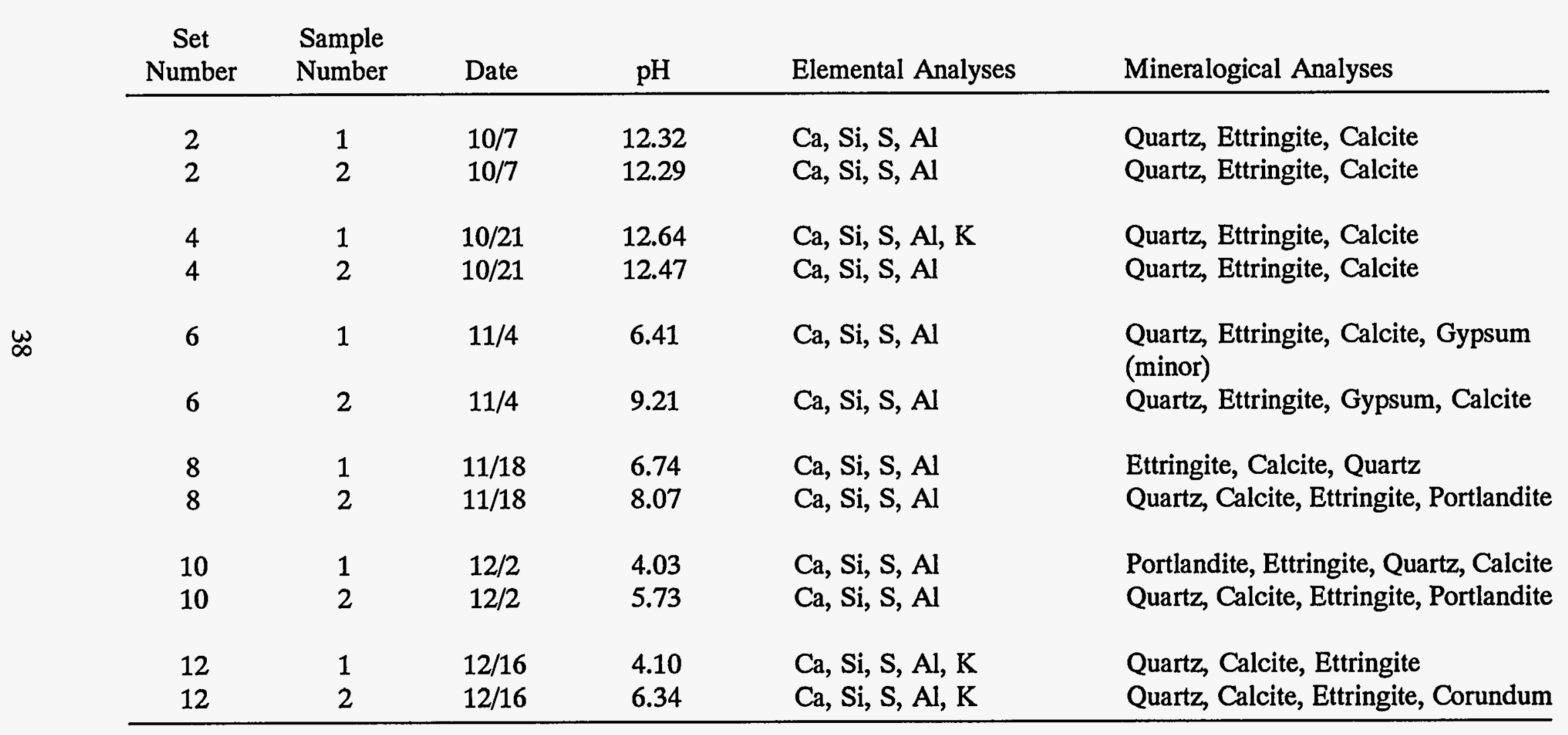




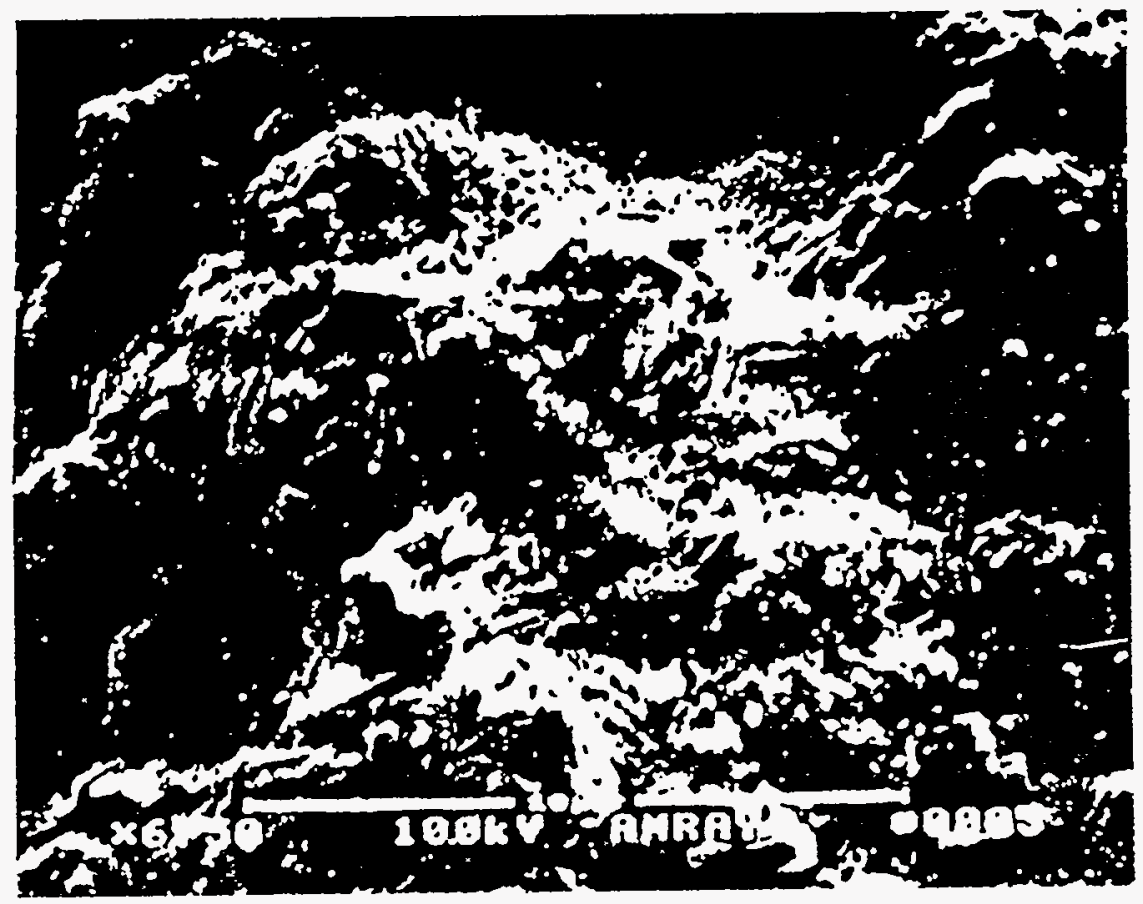

Figure 5. SEM Photomicrograph of $10 \%$ Metal Oxide-Hydroxide Hazardous Waste Mixed with 90\% ICCT Colorado-Ute AFBC Ash

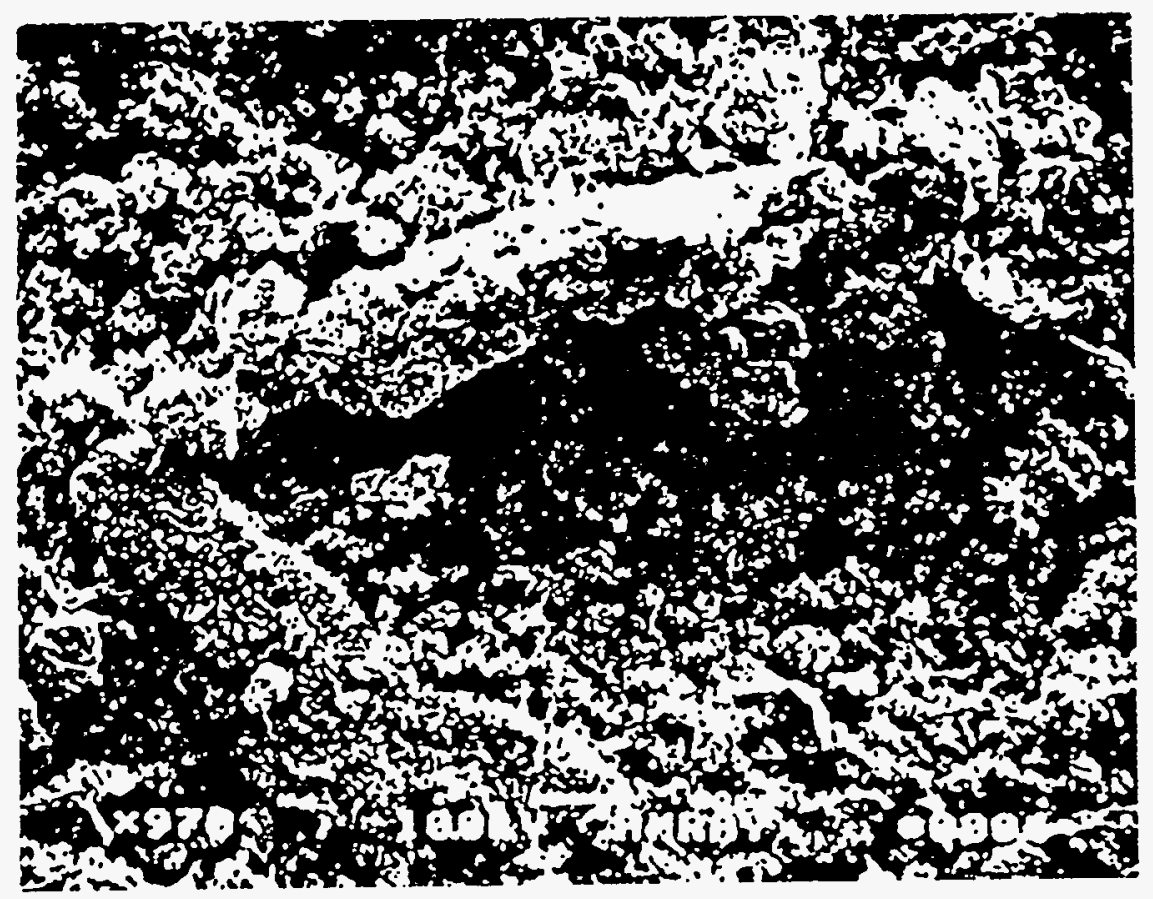

Figure 6. SEM Photomicrograph of $10 \%$ Metal Oxide-Hydroxide Hazardous Waste Mixed with $90 \%$ ICCT Colorado-Ute AFBC Ash 
Solid-State ${ }^{13} \mathrm{C}$ NMR Investigation of Pentachlorophenol Adsorbed on TVA AFBC Waste

Solid-state ${ }^{13} \mathrm{C}$ NMR studies were conducted in an effort to determine directly the adsorbed organic compounds on coal fly ash and to measure the strength of the bonding interaction between coal fly ash and the organic compound adsorbed. It is possible to observe the ${ }^{13} \mathrm{C}$ NMR resonances of the adsorbed compounds on fly ash if the following conditions are met: (1) the use of jumbo probe ( $2.5 \mathrm{~g}$ of sample) and (2) long pulse delay time (120 s or longer) to compensate for long relaxation times. The most successful experiments were those using single pulse excitation. However, such experiments take a considerable amount of time to perform. The resulting data, however, should be quantitative. ${ }^{13} \mathrm{C}$ cross-polarization experiments are most successful for those types of compounds having hydrogens. The experiments are less time consuming. However, the optimum contact time must be determined for each compound. Because the fly ash contains considerable amounts of paramagnetic impurities, the observed resonances can be broadened and the chemical shift of the carbon resonance ill-defined. This will preclude any effort to determine bonding strength for some adsorbed species.

Technical grade pentachlorophenol in methylene chloride was added to TVA AFBC ash to give a concentration of $20 \mathrm{mg}$ of pentachlorophenol per gram fly ash. Figure 7a shows the ${ }^{13} \mathrm{C}$ SPE/MAS spectrum of technical grade pentachlorophenol. The NMR spectrum of coal fly ash with sorbed pentachlorophenol is shown in Figure $7 \mathrm{~b}$. In Figure $7 \mathrm{~b}$, the ipso carbon of pentachlorophenol sorbed on the fly ash shifted to $169 \mathrm{ppm}$ from $148 \mathrm{ppm}$ for the pentachlorophenol alone (Figure 7a). This shift is quite significant and suggests that there is a strong bonding interaction of pentachlorophenol and the TVA AFBC fly ash.

Figure 7c shows the ${ }^{13} \mathrm{C}$ SPE/MAS spectrum of the pentachlorophenol adsorbed on the fly ash after leaching with water. An enhancement of the carbon with the oxidehydroxide attached is observed at $-170 \mathrm{ppm}$. The CP/MAS spectrum of the same sample (Figure 7d) shows an enhanced aromatic carbon intensity but no ipso carbon resonance. These spectra suggest that water molecules may be near carbon sites providing rapid relaxation of the carbon spin state and a source of hydrogens for cross-polarization of carbon to be effective.

Additional solid-state NMR experiments are needed to properly evaluate the technique as a means to study directly the adsorption properties of organic hazardous compounds; however, a detailed study was outside the scope of this project. 


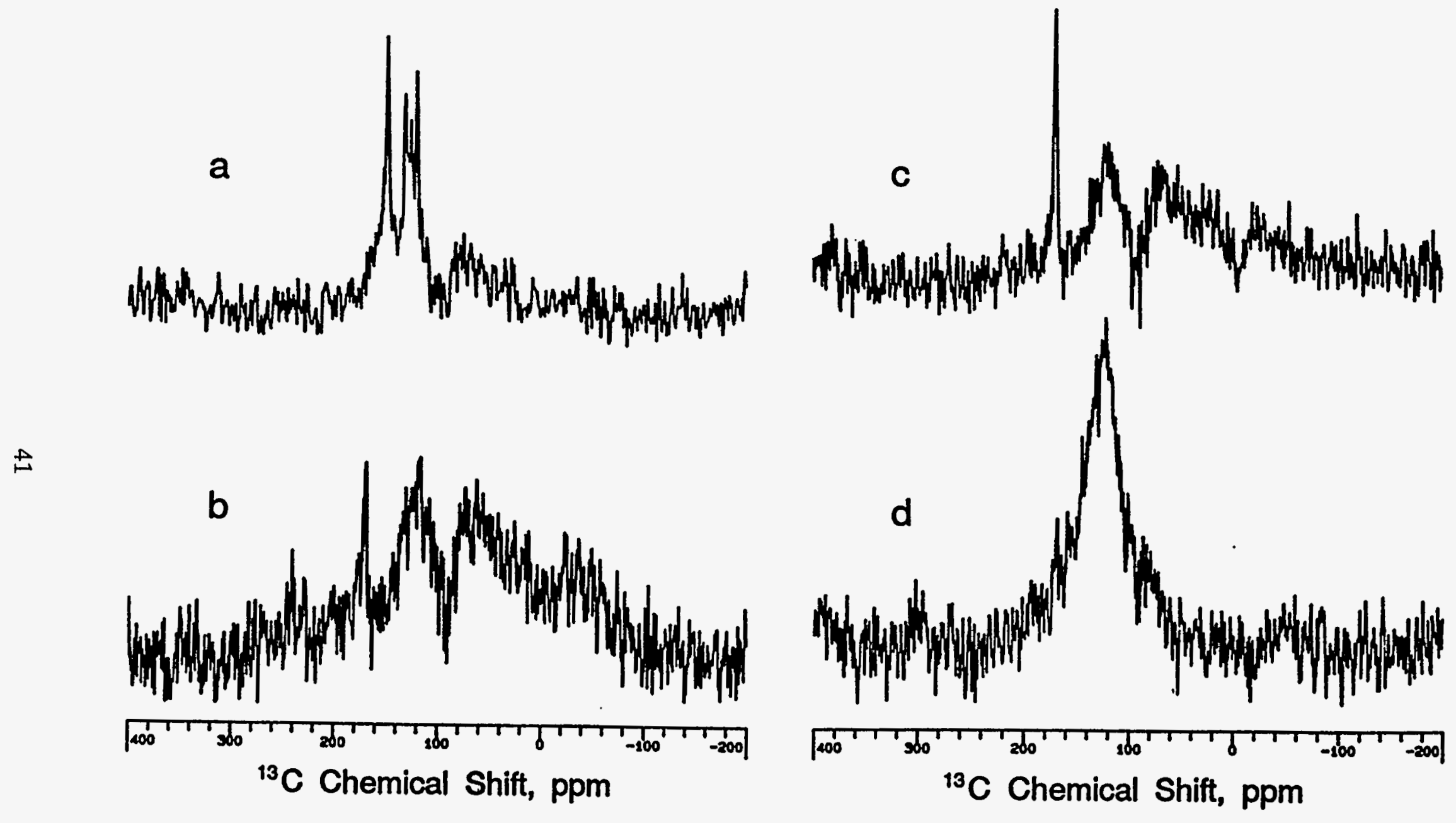

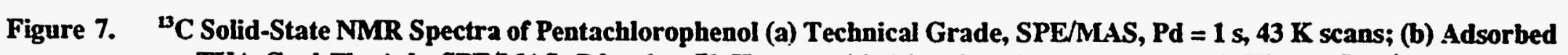
on TVA Coal Fly Ash, SPE/MAS, Pd = $1 \mathrm{~s}, 72 \mathrm{~K}$ scans; (c) After Leaching Fly Ash with Water, SPE/MAS, Pd = 1 s, $72 \mathrm{~K}$ scans; (d) After Leaching Fly Ash with Water, CP/MAS, ct $=5 \mathrm{~ms}, \mathrm{Pd}=1 \mathrm{~s}, 65 \mathrm{~K}$ scans. 


\section{CONCLUSIONS}

The stabilizing effects of ICCT wastes on four selected hazardous wastes were investigated using the waste mixing ratio technique. However, it was found that chromium was leached from the Laramie River Station spray dryer waste (2 ppm) and the TVA spray dryer waste $(0.2 \mathrm{ppm})$ alone. Thus, these materials were not mixed with metal-plating sludge in an effort to stabilize the metal-plating sludge waste. For all four ICCT wastes mixed with the metal oxide-hydroxide waste, no cadmium was detected in the leachates from any of the ratio mixtures. Mixing the metal oxide-hydroxide waste with the clean coal wastes, thus, appears to reduce the leachability of cadmium from the waste.

Semivolatile analyses were performed on the filtrates from ratio mixtures of the four ICCT wastes, with the API separator sludge. Alkyl substituted pyridine compounds were detected in some ratio mixtures but not others. It is postulated that the higher carbon content of the AFBC ash may have some effect on the solubility of the pyridine compounds. Because of the chemical complexity of the API separator sludge, no conclusions concerning stabilization of the sludge by the ICCT wastes can be made. Analyses of the filtrates from the ratio mixtures involving the creosote-contaminated soil with the Colorado-Ute AFBC ash indicate that the bulk sample of creosote-contaminated soil was not homogeneous. Despite the fact that the creosote-contaminated soil was not homogeneous, the compounds leached from the $100 \%$ creosote-contaminated soil samples were not detected in any of the filtrates of the ratio mixtures.

The results obtained from the ratio mixtures involving the API separator sludge and creosote-contaminated soil indicate that actual hazardous organic wastes are too complex for initial evaluation of the ability of combustion solid wastes to stabilize organic wastes. However, it can be concluded that the basic characteristics of the ICCT wastes may be used to stabilize acidic components of hazardous wastes.

Attempts to study the stabilizing effects of the ICCT wastes mixed with Aroclor 1260 were unsuccessful because of the physical nature of the material.

Nonequilibrium weathering experiments were conducted in which the behavior of ICCT waste/hazardous waste mixtures in an oxidizing media was studied. Cadmium was not detected above the detection limit of $0.01 \mathrm{mg} / \mathrm{L}$ in any leachates. However, an increase in chromium in the leachates was observed after the sixth week. 
Modified-batch equilibrium studies of mixtures of the ICCT wastes with the hazardous wastes indicated no organic priority pollutants in any of the leachate samples. It has been observed that the concentration of the organics (carboxylic acid and/or esters) in the leachates decreased over a sampling period of 6 months.

$\mathrm{X}$-ray diffraction, scanning electron microscopy, and energy dispersive X-ray techniques were used to study the mineralogy of the TVA and Colorado-Ute AFBC wastes, the metal oxide-hydroxide waste, the API separator sludge waste, and mixtures thereof. For the TVA AFBC waste mixed with metal oxide-hydroxide hazardous waste, ettringite was found to be the most abundant phase. Calcium, silicon, and sulfur were the dominant elements identified. Mineralogically, samples of the TVA AFBC waste mixed with the API separator sludge waste were found to be similar to samples of the TVA AFBC/metal oxide-hydroxide mixture. However, four mineral phases were tentatively identified in the TVA AFBC/API separator sludge samples that were not found in any mixtures of the TVA AFBC ash and metal oxide-hydroxide waste. Elemental analyses show that calcium, silicon, and sulfur are again the major components of the TVA AFBC/API separator sludge samples. It was found that quartz was the dominant phase identified in samples of the Colorado-Ute ICCT waste mixed with the metal oxidehydroxide hazardous waste. Other major phases identified were calcite and ettringite. Calcium, silicon, sulfur, and aluminum were the elements identified in these samples.

Solid-state ${ }^{13} \mathrm{C}$ NMR spectra were obtained for pentachlorophenol adsorbed on TVA AFBC ICCT waste. These preliminary experiments have shown that hazardous waste material can be directly observed on the ICCT waste and that changes in the chemical shift of the phenolic carbon of pentachlorophenol should be a measure of the bonding strength between the two waste materials. However, additional NMR experiments are needed to properly assess the technique as a means to study adsorption properties of hazardous wastes and ICCT wastes. 


\section{ACKNOWLEDGMENT}

We express appreciation to the U.S. Department of Energy for funding of this work under Cooperative Agreement No. DE-FC21-86MC11076 and to Electric Power Research Institute for funding by Contract No. RP3176-03.

\section{DISCLAIMER}

Mention of specific brand names or models of equipment is for information only and does not imply endorsement of any particular brand. 


\section{REFERENCES}

Ainsworth, C.C., and D. Rai, 1987, Chemical Characterization of Fossil Fuel Combustion Wastes, EPRI EA-5321. Palo Alto, CA: Electric Power Research Institute.

Carlos-Gibergues, A., and P.C. Aitcin, 1986, Analysis of the Properties of a Silico Aluminus (Class F) Fly Ash. Material Research Society Symposium Proceedings: Fly Ash and Coal Conversion By-Products: Characterization, Utilization, and Disposal II, 65: 81-192.

Caruccio, F.T., 1968, An Evaluation of Factors Affecting Acid Mine Drainage Production and the Groundwater Interactions in Selected Areas of Western Pennsylvania. Pap. Symp. Coal Mine Drain. Res., 2nd, 107-152.

Essington, M.E., 1989, Trace Element Mineral Transformations Associated with Hydration and Recarbonation of Retorted Oil Shale. Environ. Geol. Water Sci. 13: 59-66.

Grutzeck, M.W., W. Fajun, and D.M. Roy, 1985, Retardation Effects in the Hydration of Cement-Fly Ash Pastes. Material Research Society Symposium Proceedings: Fly Ash and Coal Conversion By-Products: Characterization, Utilization, and Disposal I, 43: $65-72$.

Hayashi, S., and K. Hayamizu, 1991, Chemical Shift Standards in High Resolution SolidState NMR (1) ${ }^{13} \mathrm{C},{ }^{29} \mathrm{Si}$, and ${ }^{1} \mathrm{H}$ Nuclei. Bull. Chem. Soc. Jpn. 64: 685-687.

Hemmings, R.T., and E.E. Berry, 1988, On the Glass in Coal Fly Ashes: Recent Advances. Material Research Society Symposium Proceedings: Fly Ash and Coal Conversion By-Products: Characterization, Utilization, and Disposal IV, 113: 3-38.

McCarthy, G.J., 1988, X-Ray Powder Diffraction for Studying the Mineralogy of Fly Ash. Material Research Society Symposium Proceedings: Fly Ash and Coal Conversion By-Products: Characterization, Utilization, and Disposal IV, 113:75-86.

Rai, D., C.C. Ainsworth, L.E. Eary, S.V. Mattigod, and D.R. Jackson, 1987, Inorganic and Organic Constituents in Fossil Fuel Combustion Residues, Volume 1: A Critical Review, Palo Alto, CA, EPRI EA-5176.

Spackman, L.K., K.D. Hartman, J.D. Harbour, and M.E. Essington, 1989a, Adsorption of Oxyanions by Spent Western Oil Shale: I. Arsenate. Environ. Geol. Water Sci. 15: 83-91.

Spackman, L.K., K.D. Hartman, J.D. Harbour, and M.E. Essington, 1989b, Adsorption of Oxyanions by Spent Western Oil Shale: II. Selenite. Environ. Geol. Water Sci. 15: 93-99. 
Sullivan, P.J., J.L. Yelton, and K.J. Reddy, 1988, Iron Sulfide Oxidation and the Chemistry of Acid Generation. Environ. Geol. Water Sci., 11: 289-295. 